\title{
Adana Vilayeti Hükümet Konakları
}

\author{
Government Offices in Adana Province
}

\author{
나 Nur UMAR, (1) Cengiz CAN
}

ÖZ

18.yy başında "Batııılaşma” olarak adlandırılan “yenilenme” dönemine girmiş olan Osmanlı Devleti, yenilenmenin en etkin düzeyini 19.yy'da görmüştür. "1839 Tanzimat Fermanı", Osmanlı kamu kurumlarında köklü değişimlere yol açmış ve bunun sonuçlarından biri olarak devletin yeni işleyişini yansıtan mimari yapı türleri ortaya çıkmıştır. Bu yapı türleri; yönetim, eğitim, ulaşım, ticaret, sağlık vb. alanlarında farklılık gösterirken, yönetim alanında ilk dikkati çeken yapılar ise "hükümet konakları" olmuştur. Devletin bölgedeki iktidarını da simgeleyen hükümet konakları, 19.yy'ın ikinci yarısı ile birlikte İstanbul başta olmak üzere bütün Osmanlı coğrafyasında varlığını hissettirmiştir. Adana ve çevresi ise bu dönemde ziraatin gelişmesi sonucu, bölgenin tarım merkezi haline gelerek önem kazanmıştır. 1864 yılına kadar bağımsız bir eyalet olan Adana'ya, 1867 yılında vilayet statüsü verilmiştir. Bu süreçte başta vilayet merkezi olmak üzere tüm sancak ve kazalarda hükümet konaklarının varlığından söz etmek mümkündür. Bu araştırma kapsamında, Adana Vilayeti sınırları içerisinde hangi bölgelere hükümet konağı yaptırıldığı veya hangi projelerin hazırlandığı, yapıların mimari özellikleri, günümüze ulaşıp ulaşmadıkları, günümüzdeki fiziki durumları ile koruma sorunları incelenmiştir. Çalışma, literatür-arşiv taraması ve alan çalışması olmak iki aşamada gerçekleştirilmiştir. İlk aşamada, Adana'nın vilayet olduğu dönemde; 1867-1922 yılları arasındaki yapılar ile benzer üslupları içermek kaydıyla vilayet statüsünün değiştirildiği 1922-30 yılları arasındaki yapılar tespit edilerek listelenmiştir. 06.02.2014-15.07.2015 tarihleri arasında gerçekleştirilen ikinci aşamada ise, 19.yy Adana Vilayeti sınırları içerisinde kalan il ve ilçe merkezlerine, hazırlanan yapı listesi ile gidilerek yerinde durum tespitleri yapılmıştır. Elde edilen veriler sonucunda hazırlanan çalışma ile kent tarihi, mimarlık tarihi ve çağdaş koruma bilimine katkı sunulması hedeflenmektedir.

Anahtar sözcükler: 19. yüzyıl; Adana; hükümet konakları; mimari miras.

\section{ABSTRACT}

Entering the "Westernization" process in the $18^{\text {th }}$ century, the Ottoman Empire experienced the most drastic level in the 19th century. "The Imperial Edict of Reorganization of 1839" led fundamental changes in the public institutions and new kinds of architectural structures emerged. While these structures varied in many areas, the first structures in the administration filed were government offices. Symbolizing state's power, these government offices made their presence felt throughout the Empire, mainly in Istanbul, in $19^{\text {th }}$ century's second half. Adana and its surrounding areas emerged as the agriculture center as a result of the agricultural boost. Adana's status, which was independent state until 1864, has been changed to province in 1867. In the scope of this research, an analysis has been made on the whereabouts of these offices in the Adana Province or the prepared projects; the features of the structures; whether they have reached today or not and their current status and the problems in the preservation of them. The study was conducted in two phases: literature and achieve review and field work. In the first phase, the structures of the period of 1867-1922, as well as the structures of the period of 1922-1930 with similar genre, were determined and listed. In the second phase - lasted between 06.02.2014-15.07.2015 - a field assessment was made with the list of structures in the center and other districts. With the results, the study aims at contributing to the architectural history of the city and preservation science field.

Keywords: $19^{\text {th }}$ century; Adana; government offices; architectural heritage.

Yıldız Teknik Üniversitesi Mimarlık Fakültesi, Mimarlık Anabilim Dalı, İstanbul

Başvuru tarihi: 07 Mart 2018 - Kabul tarihi: 06 Kasım 2019

İletişim: Nur UMAR. e-posta: nur.umar@gmail.com

○ 2019 Yıldız Teknik Üniversitesi Mimarlık Fakültesi - @ 2019 Yıldız Technical University, Faculty of Architecture 


\section{Giriş}

Osmanlı Devletinde değişim süreci, 18.yy başında "Lale Devri" olarak adlandırılan "Batılılaşma Döneminde" başlamış olup, 1839 Tanzimat Fermanı ile birlikte devletin bütün kurum ve kuruluşlarında düzenlemeler yapılmasıyla sonuçlanmıştır. Bu süreçte yönetim; idari, eğitim, sağlık, savunma, ulaşım, üretim ve sivil mimarlık yapıları mekânsal olarak yeniden düzenlenmiştir. Klasik Osmanlı mimarlık yapılarının yerini Batt ile bütünleşmeyi sağlayacak yapı tipleri almıştır.

19. yy'a kadar Osmanlı kentlerinde görev yapan kamu görevlileri geleneksel yapıları kiralayarak kullanmıştr. ${ }^{1}$ Bunu izleyen dönemde ise kendine has mimari üsluba sahip, kâgir, gösterişli kamu yapıları tasarlanarak hayata geçirilmiştir. 'Ebniye-i miriye' ${ }^{2}$ olarak da adlandırılan bu yapılara ait ilk örnekler dönemin başkenti İstanbul'da verilmiş olup, 19. yy ikinci yarısından itibaren ise taşrada inşa edilmeye de başlanmıştı. ${ }^{3}$ Yapıların mimari niteliği, devletin söz konusu bölgeye ne kadar önem verdiğini de göstermektedir. Bu nedenle, zengin vilayet ve sancaklarda; farklı uygulamalar, üslup açısından daha nitelikli veya gösterişli örneklere rastlanmaktadır. ${ }^{4}$

\section{Yüzyıl Adana Vilayeti ve Hükümet Konakları}

19.yy, Adana bölgesinde siyasi değişimlerin yaşandığı bir dönem olmuştur. Adana, 1832-40 yılları arasında Mehmet Ali Paşa'nın oğlu İbrahim Paşa'nın yönetiminde kalmış olup, bu dönemde uygulanan politikalar sonucunda yerleşik bir tarım merkezine dönüşmüştür. ${ }^{5} 1860^{\prime}$ lı yıllarda Amerikan İç Savaşının (1861) başlaması, İngiltere'yi pamuk ihtiyacını Mısır, Hindistan ve Anadolu'dan karşılamaya yöneltmiştir. Böylece 1861 yılından itibaren Adana şehrinin içinde bulunduğu, pamuk üretimine elverişli olan Çukurova bölgesi küresel önem kazanmış olup; bu tarihten itibaren vilayet ve sancak merkezlerinde, merkezi yönetim ya da vali öncülüğünde halkın yardımları ile kamu yapıları yaptrılmaya başlanmıştır.

1864 yılına kadar bağımsız bir eyalet olan Adana, 1867 yılında dört sancak ile birlikte vilayete dönüştürülmüştür. Vilayet hududunun en geniş olduğu 1888-1922 yıllarındaki sınırlar, çalışma alanı için geçerli kabul edilmiştir. Ancak mimari üslubun ve yapım tekniğinin benzerlik göstermesi nedeniyle dönem 1867-1930 olarak genişletilmiştir. Bu dönemde vilayet; Adana Sancağı, Cebel-i Bereket Sancağı, Kozan Sancağı, Mersin Sancağı, İçel(İçil) Sancağı olmak üzere 5 sancak ve Adana, Karaisalı, Ceyhan, Kozan, Feke, Saimbeyli, Tufanbeyli, Kadirli, Yarpuz, Bahçe, İslahiye, Hassa, Payas, Tarsus, Mersin, İçel (İçil), Anamur, Mut, Ermenek, Gülnar olmak üzere 20 kazadan oluşmaktadır (Şekil 1). Gü-

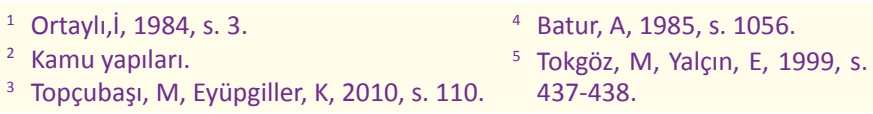

\footnotetext{
4 Batur, A, 1985, s. 1056.

5 Tokgöz, M, Yalçın, E, 1999, s. 437-438.
}

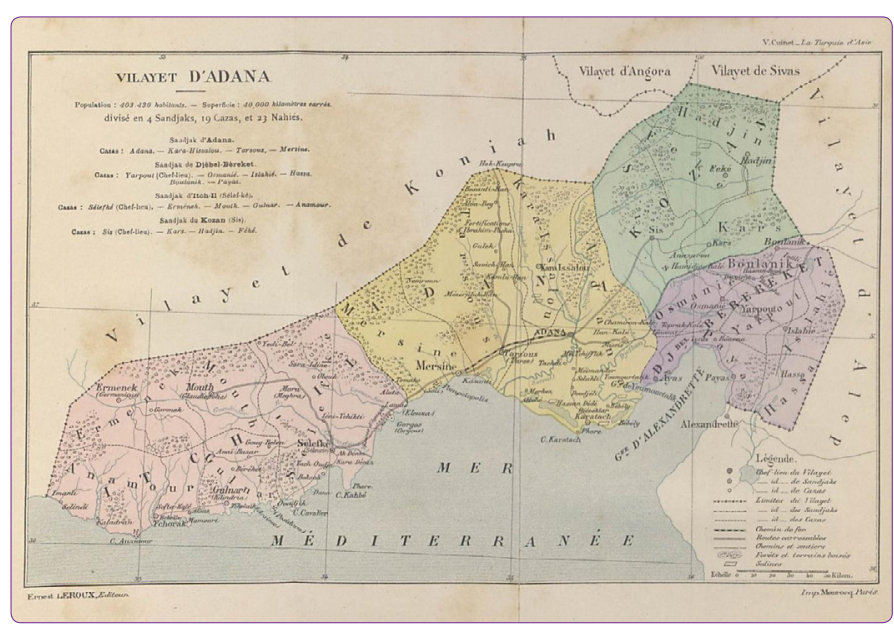

Şekil 1. 19. yy Adana Vilayeti Haritası (Kaynak: Cuinet, V., (1894). La Turquie d'Asie, Isis Yayınları, Istanbul).

nümüzde bu sancak ve kazalar; Adana, Mersin, Karaman, Osmaniye, Hatay ve Gaziantep illerinin sınırları içerisinde yer almaktadır. Çalışma kapsamında, sancak ve kaza merkezlerindeki Tanzimat sonrası inşa edilen hükümet konakları ele alınmaktadır.

Çalışmada izlenen yöntem; literatür ve arşiv taraması, Osmanlıca belgelerin tercüme edilmesi, arazi çalışması ile beraber yerinde tespit yapılması, listeleme, koruma sorunlarının ve metotlarının araştırılması olarak sıralanabilmektedir.

Literatür ve arşiv taraması aşamasında, Adana Vilayeti 'ne bağlı olan tüm yerleşimler İstanbul, Ankara, Adana ile ilgili bölgeleri de kapsayacak şekilde kütüphane ve enstitülerde, uluslararası kütüphanelerin veri tabanlarında detaylı olarak araştırılmıştır. Başbakanlık Osmanlı Arşivi'nin dijital veri tabanında her bir bölge için ayrı aramalar yapılarak, hangi kamusal birimlerden ve yapılardan söz edildiği tespit edilerek belirlenen hükümet konağı yapıları bulundukları il/ilçe'nin adı altında listelenmiştir.

Başbakanlık Osmanlı Arşivi taramalarında bölgedeki hükümet konağı yapılarına dair elde edilen belgeler ve projeler de tercüme edilerek çalışma içerisinde değerlendirilmiştir.

Alan çalışmasında, 19. yy Adana Vilayeti sınırları içerisinde kalan il ve ilçe merkezlerine, tespit edilen yapı listesi ile gidilmiştir. Öncelikle resmi kurumlardan bilgiler alınmış, sonrasında yerel halk ile görüşme yapılarak, onların anı ve tanıklıklarından yararlanılmıştır. Bu verilerden yola çıkarak listelediğimiz yapıların konumları saptanmış, yerine gidilerek yapıların mimarisi ve korunmuşluk durumları incelenmiştir.

Osmanlı arşivinde, salnamelerde ve alanda yapılan incelemeler sonucunda 20 kazanın tümünde hükümet konağı bulunduğu anlaşılmıştır. Bunlardan 16 tanesi hükümet konağı işlevi gözetilerek tasarlanmış olup, 4 tanesi ise gele- 
neksel konutların bu amaç doğrultusunda kullanımından oluşmaktadır. Çalışma kapsamında; sadece hükümet konağı olarak inşa edilmiş olan 16 yapının mevcut durumları incelenmiştir. 16 hükümet konağından günümüze 6 tanesi ulaşmış olup, 10 'u ise farklı sebeplerden dolayı yıkıldığı anlaşılmıştır.

\section{Adana Hükümet Konağı}

Yapı, Sultan II. Abdülhamid döneminde Adana valisi olan Süleyman Bahri Paşa tarafindan 1899-1901 yılları arasında yaptırılmıştır. ${ }^{6}$ Serveti Fünun Dergisinde yapının açılışı fotoğrafiyla birlikte duyurulmuştur (Şekil 2). İnşa edilmesi için idadi mektebi, telgrafhane, belediye binası gibi kamu yapılarının yoğunlaştğı, kente hâkim bir konum seçilmiştir.

Bina eğimsiz bir arazi üzerine bodrum + zemin + iki kat olarak inşa edilmiştir. Dikdörtgen formunda, ana giriş aksı ve köşeleri dışa doğru çıkmalıdır (Şekil 3). Zemin katta ana giriş holünün karşısında kapı, onun yanında ise merdiven bulunmaktadır. Ayrıca bodrum katta güney yönünde bir giriş daha yer almaktadır. Giriş aksına dik olacak şekilde kuzey-güney doğrultusunda ana koridor uzanmakta, bu koridorun doğu ve batısında odalar sıralanmaktadır.

Bodrum kat, zemin kat alanı ile aynı büyüklükte ve $17.65 \times 45.65 \mathrm{~m}$ boyutlarındadır. ${ }^{7}$ Bu kata dışarıdan güney cephede yer alan mermer bir merdivenle, içeriden de tek kollu betonarme bir merdivenle ulaşmak mümkündür. Birinci ve ikinci kat boyutları bodrum kattan daha dar olmasına rağmen plan şeması benzerlik göstermektedir. Son katta koridor daha kısa tutulmuş, özgün halinde sağ ve sol kısımlarda simetrik olacak şekilde boş kalan mahaller teras olarak bırakılmıştır.

Giriş aksına göre simetrik bir cepheye sahip olan yapıya çift kollu merdivenle girilmektedir. Giriş kapısının üzerinde $76 \times 116 \mathrm{~cm}$ boyutlarında bir kitabe, onun üzerinde ise balkon yer almaktadır. Binanın kütlesel etkisi silme ve pilastrlarla hafifletilmiştir. Pencere kenarları profilli söveli olup, her pencerenin üzerine üçgen alınlık yerleştirilmiştir. Giriş kapısı ve kitabesi de profilli sövelerle vurgulanmaktadır.

Yapı subasman seviyesine kadar kesme taş, devamında ise tuğla malzeme ile yığma olarak inşa edilmiştir. Özgün döşeme ve merdivenleri ahşap olarak tasarlanmış fakat günümüzde betonarmeye çevrilmiştir. ${ }^{8}$ Ana giriş merdivenlerinde mermer; pencere ve kapı doğramalarında ise ahşap kullanılmışttr.

Yapı 1945 ve 1998 depremlerinde hasar görmüş olup, 1998 depremi sonrasında restore edilerek günümüzde Seyhan Kaymakamlığı olarak kullanılmaktadır. 1998 depremi öncesinde de çok sayıda müdahale geçiren yapının cephesine ilişkin ilk değişiklik; 1936 yılına ait fotoğraflarda

\footnotetext{
6 Servet-i Fünun Dergisi, 1901, sayı: Adana Kültür Varlıklarını Koruma 1894 (552), s. 1. Kurulu Arşivi.

Adana Hükümet Konağı Dosyası, ${ }^{8}$ Ulaş, M, 2011, s. 54-56.
}

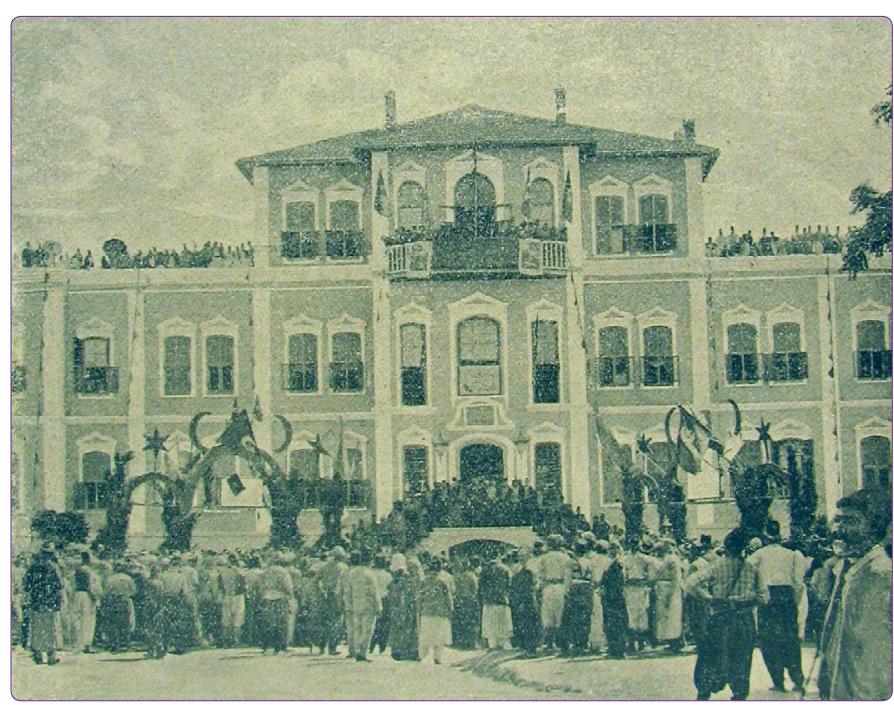

Şekil 2. Adana Hükümet Konağı Açılışı (Kaynak: Servet-i Fünun Dergisi, 1894 (552), sayfa: 1, 27 Eylül 1317).

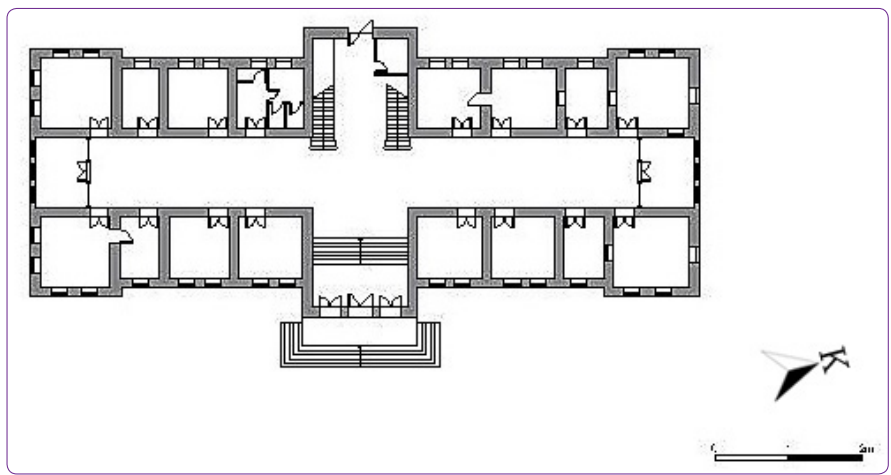

Şekil 3. Adana Hükümet Konağı Planı (Kaynak: Nur Umar arşivi).

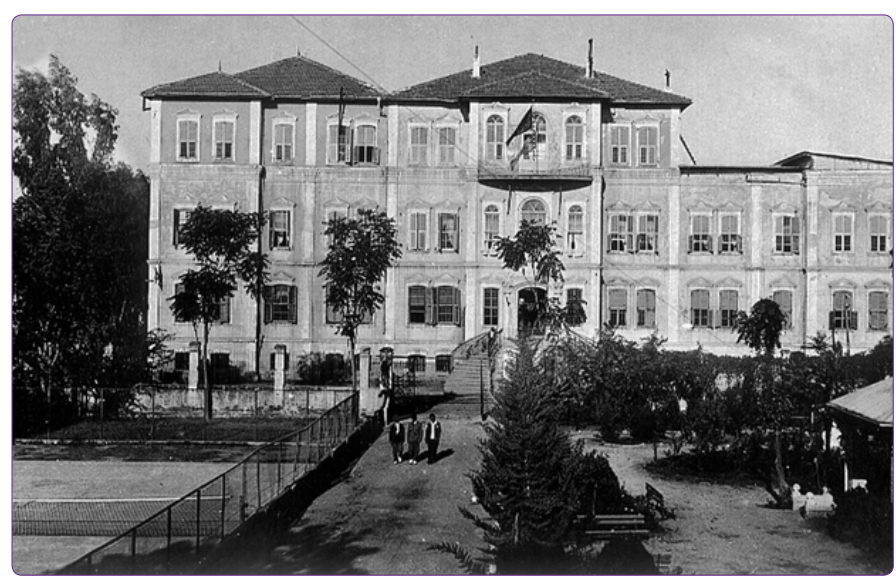

Şekil 4. Adana Hükümet Konağı II. Dönem (Kaynak: Adana Hükümet Konağı Dosyası, Adana Kültür Varlıklarını Koruma Kurulu Arşivi).

görüldüğü üzere son katta güney yönünde yer alan teras kapatılması ve cephede simetrinin kaybolmasıdır (Şekil 4). Elde edilen fotoğraflardan yapının ilerleyen yıllarda dönemin mimari anlayışına benzer şekilde cephenin yenilendiği tespit edilmiştir (Şekil 5). Binanın kemerli, üçgen alınlıklı pencereleri dikdörtgen formuna dönüştürülmüş, çevre- 


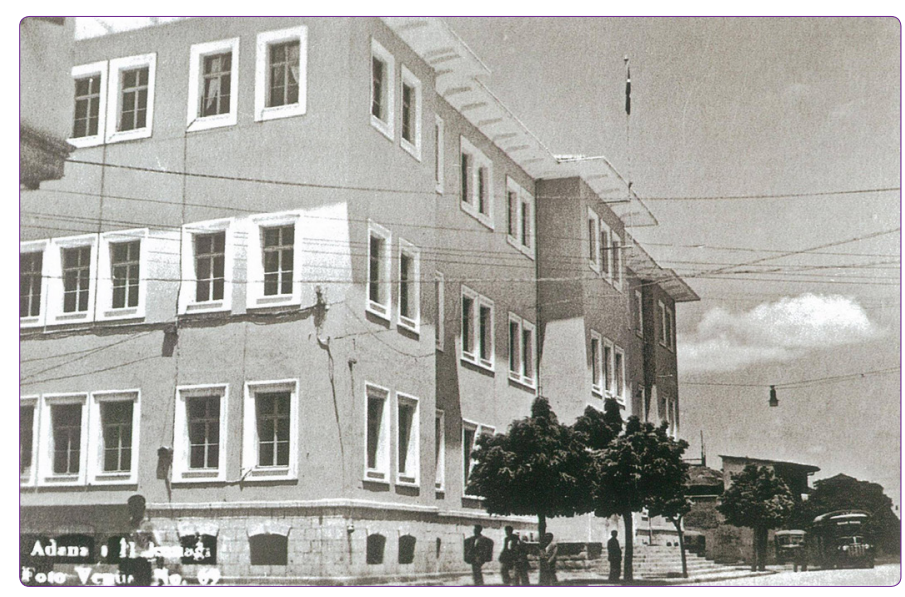

Şekil 5. Adana Hükümet Konağı III. Dönem (Kaynak: Adana Hükümet Konağı Dosyası, Adana Kültür Varlıklarını Koruma Kurulu Arşivi).

si profilli sövelerle vurgulanmıştr. Giriş kapısı dikdörtgen forma çevrilmiş, çevresi mermer ile kaplanarak modern bir görünüm kazandırılmıştır. Girişte yer alan çift kollu merdiven kaldırılmış, yerine korkuluksuz üç kollu, altı basamaklı dikdörtgen sahanlıklı bir merdiven eklenmiştir. Binanın iç merdiven bölgesinin taşıyıcı sistemi betonarmeye dönüştürülmüş, en üst kata sonradan saçak ilave edilerek çat-nın formu değiştirilmiştir. En az müdahaleye uğrayan kısım olarak bodrum kat özgünlüğünü muhafaza etmiş, ancak yol kotunun yükselmesinden ve sıvalarının temizlenmesinden ötürü cephedeki algısı değişmiştir. 1998 depreminin ardından yapıda incelemeler yapılmış, ek bina ile üçüncü kata sonradan eklenen bölümlerin yıkılması ve binanın özgün formuna getirilmesi kararlaştrılmıştır. ${ }^{9}$ Ahşap olan kat döşemelerinin betonarme ile yenilenmesi, iç kısımda yer alan betonarmeye dönüştürülmüş merdivenin ise çelik sistemle değiştirilmesi önerilmiştir. Günümüzde ilk yapıldığı dönemdeki üslubuna uygun şekilde restore edilmiş, sadece giriş kapısı tek kollu bir merdiven şeklinde düzenlenerek, engelli rampası eklenmiştir.

\section{Cebel-i Bereket (Yarpuz) Hükümet Konağı}

Osmaniye ili, merkez ilçesi, Yarpuz Köyünde Hazine'ye ait 106 ada 11 parselde yer almaktadır. Cebel-i Bereket Sancağı merkezinin Payas'tan Yarpuz Köyüne taşınmasının ardından 1878 (Hicri 1296) yılında inşa edilmiştir. Bu tarih, Sultan II. Abdülhamit saltanatına ve Ziya Paşa'nın da Adana valiliğine denk gelmektedir.

Bina, düz bir arazi üzerinde giriş bölümü zemin +1 katlı, yan kanatları tek katlı tasarlanarak inşa edilmiştir. Dikdörtgen planlı olup, doğu-bat doğrultusunda uzanmaktadır. Binanın ana cephesi ve giriş kapısı güneyde yer almaktadır.

Bina; giriş katında tam orta aksta yer alan $4.30 \times 8.30 \mathrm{~m}$ boyutlarında bir hol ile holün her iki tarafinda simetrik olarak yan yana dizilmiş, arka cephede dört ayrı girişi olan

\footnotetext{
Adana Hükümet Konağı Dosyası, Adana Kültür Varlıklarını Koruma Kurulu Arşivi.
}

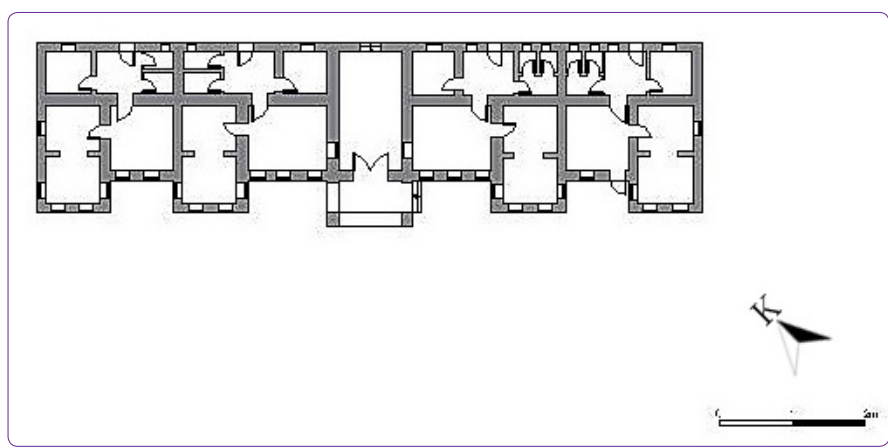

Şekil 6. Yarpuz Hükümet Konağı Planı (Kaynak: Nur Umar arşivi).

mekânlardan oluşmaktadır. Bu mekânlar $8.75 \times 10.70 \mathrm{~m}$ ile $9.90 \times 10.70 \mathrm{~m}$ boyutlarında olup, kendi içlerinde odalara ayrılmaktadır. Ana holün üst katında $4.30 \times 8.30 \mathrm{~m}$ boyutlarında bir salon ile bu salondan ön cepheye açılan, üç basamakla yükseltilmiş $4.30 \times 3.30 \mathrm{~m}$ boyutlarında bir oda bulunmaktadır. Bu odanın makam odası olabileceği tahmin edilmektedir (Şekil 6).

Binanın ana cephesi giriş aksına göre simetriktir ve iki basamaklı bir dış merdiven ile giriş kapısına ulaşılmaktadır. Binanın giriş kısmı çıkmalı, revaklı ve sivri kemerli olup, pencere ve kapıları düz atkılıdır. Giriş cephesi, planda yan yana dizilmiş mekânların bazılarının öne çıkarılması ile hareketlilik kazanmıştır. Arka cephesi yalın ve asimetrik olup, her birim için ayrı giriş kapısı yer almaktadır. Yapı kırma çatılı olup, orta holün üzerindeki yükseltilmiş mekânın üstü kiremit, diğer yerler de çinko ile örtülüdür. Ön ve arka cephede saçaklar $70 \mathrm{~cm}$ uzunluğunda ve altları ahşap ile kaplıdır (Şekil 7 ve 8).

Bina, moloz taş malzeme üzerine sıva ile yığma yapım tekniğinde ara bölücü duvarlarda yassı tuğla kullanılarak inşa edilmiştir. ${ }^{10}$ Kat döşemesi, iç merdiven ve pencere doğramalarında ahşap, kapı doğramalarında metal kullanılmıştır.

Hükümet Konağı işlevini kaybettikten sonra bir dönem Orman Müdürlüğü hizmet binası olarak kullanılan yapı, günümüzde kullanılmamaktadır. Arşiv incelemelerinde, 2004 yılında Adana Koruma Kurulu kararı ile basit onarım kapsamında sıva, boya, pencere ve kapı doğramalarının değişimi, çatı onarımı, ıslak zeminlerde seramik kaplama, sıhhi ve elektrik tesisatının yenilenmesi gibi uygulamaların yapıldığı anlaşılmıştır. ${ }^{11}$ Günümüzde zemin döşsemesi beton şap kaplı olup, bunun da sonradan yapıldığı anlaşılmaktadır. Ahşap tavan kaplamaları özgünlüğünü korumaktadır. Orta hol ile üst kat bağlayan orijinal merdiven kaldırılarak yerine yeni bir ahşap merdiven eklenmiştir. Pencereler ve kapılar ahşap doğramalı olup, elde edilen fotoğraflarda 2004 yılında yapıldığı anlaşıımıştır. Sadece üç pencere

\footnotetext{
${ }^{10}$ Yarpuz Hükümet Konağı Dosyası, ${ }^{11}$ Adana II Kültür ve Turizm MüdürAdana Kültür Varlıklarını Koruma lüğünün 02.02.2015 tarih ve 205 Kurulu Arşivi.
} 


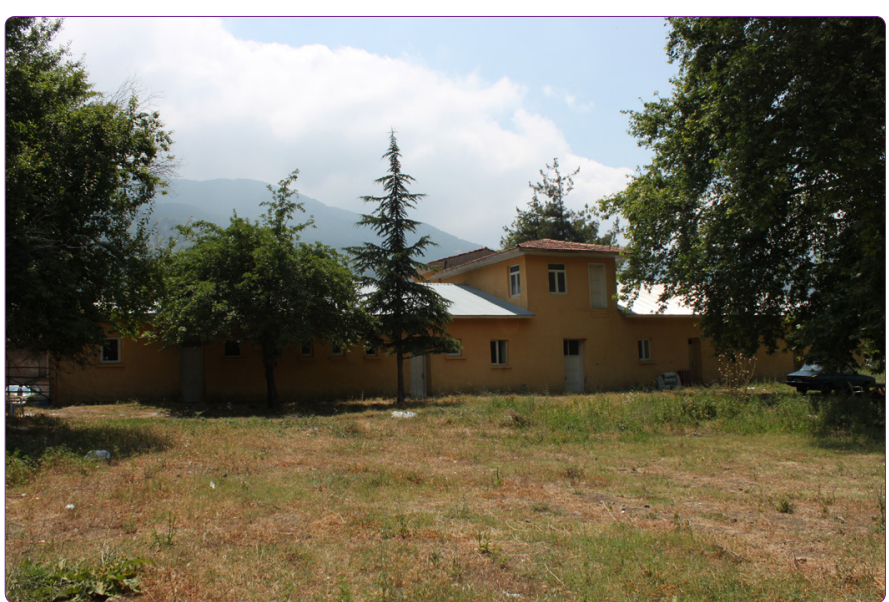

Şekil 7. Yarpuz Hükümet Konağı Arka Cephe (Kaynak: Nur Umar arşivi).

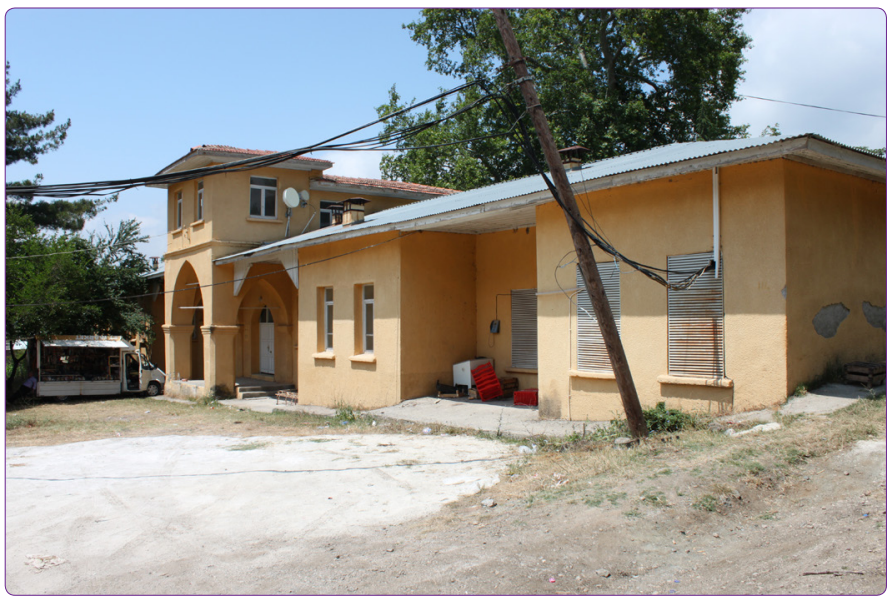

Şekil 8. Yarpuz Hükümet Konağı Ön Cephe (Kaynak: Nur Umar arşivi).

demir kepenk ile kapatılmış olduğundan, bunların doğramaları dışarıdan tespit edilememiştir. Mevcut durumda; yapının özgün mimari formunu korumakta olduğu, geçirdiği onarımlar sonucu malzeme ve detaylarda özgünlüğünü yitirdiği gözlenmiştir. Günümüzde cephede kirlenme, bitkilenme, sıvada yer yer dökülme, çinko ve demir elemanlarda korozyon ile elektrik kablosu, uydu anteni gibi elemanların oluşturduğu bir görüntü kirliliği gözlenmektedir.

\section{Mersin Hükümet Konağı}

Mersin Hükümet Konağı, Mersin ili, Akdeniz ilçesi, Cami-i Şerif Mahallesi, Uray Caddesi'nde yer almaktadır. Mersin 1864 yılında kaza olunca, hükümet dairesi olarak zaptiye dairesinin de yer aldığı toprak damlı bir bina yaptırılmıştır. Bu bina yeterli olmayınca hükümet dairesi başka bir binaya taşınmıştr. ${ }^{12}$ Osmanlı Arşivi'nde yer alan 17 Eylül 1891 tarihli belgeden anlaşıldığı üzere hükümet konağının inşası yeniden gündeme gelmiştir. ${ }^{13}$ Bu belgede, Mersin Hükümet Konağı'nın yeniden inşası için ayrılan paranın sarf izninin verilmesi ve mevcut hükümet konağının satılmak istendi-

12 Develi, H, Ş, 2001, s. 70

1868 Gömlek No :107 Fon Kodu:

${ }^{13}$ Tarih :12/S /1309 (Hicrî) Dosya No:

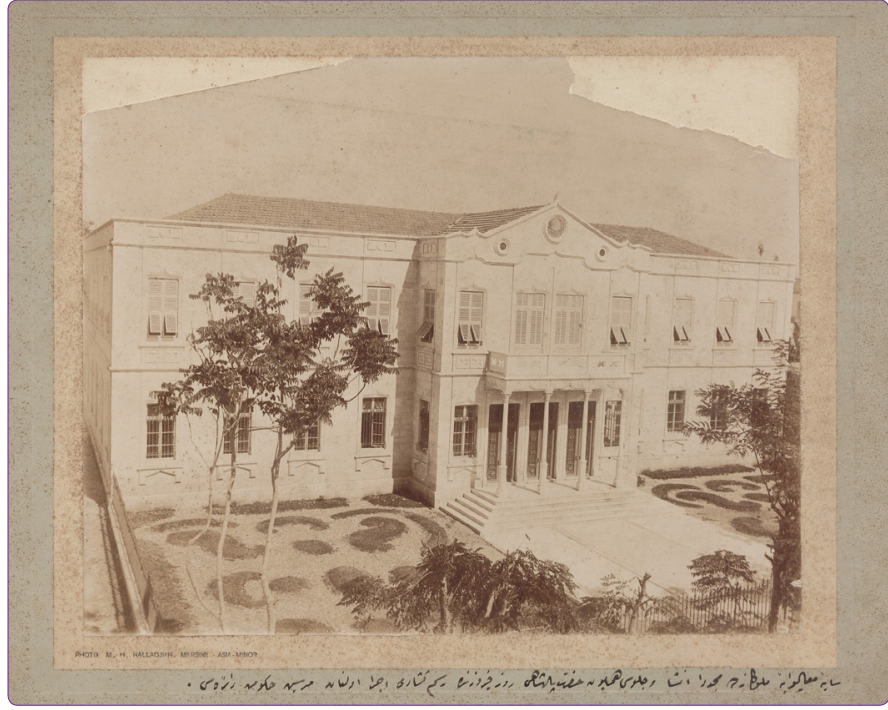

Şekil 9. Mersin Hükümet Konağı, 1906 (Kaynak: BOA, Tarih: 13/03 /1906 (Hicrî) Dosya No: 1967 Gömlek No:- Fon Kodu: FTG. f..).

ği yazmaktadır. Yine aynı yıl yazılmış olan bir başka belgede hükümet konağının yeniden inşa edilmesi konusunda vilayete başvurulması gerektiği ve değerlendirilmesinin beklendiğinden söz edilmektedir. ${ }^{14}$ Yazışmalar uzun zaman devam etmiş olup, inşaat 1901 yılında başlamıştır. ${ }^{15} \mathrm{Mu}-$ tasarrıf Cemil Bey şehrin ileri gelenlerine inşaata yardım çağrısında bulunmuştur. Halk inşaat giderlerine katkı sunmuş, Belediye Meclisi de iskele gelirini 4 yıllığına bu inşaata bağışlama kararı almıştr. ${ }^{16}$ Bina, bu katkılarla birlikte arkasında jandarma ve hapishane dairesi bulunan bir kompleks şeklinde tasarlanmışttr. ${ }^{17}$ Hükümet Konağı'nın inşası 1905 tarihinde tamamlanıp resmi açılışı yapılmış ve bazı resmi daireler Hükümet Konağı'na taşınmıştir ${ }^{18}$ (Şekil 9).

Giriş aksına göre simetrik dikdörtgen plan düzenine sahip, iki katlı ve ortası avlulu bir yapıdır. Kesme taş malzeme ile yığma olarak inşa edilmiştir. Birinci katta ana girişin her iki yanında birer oda ve karşısında üst katlara çıkan merdiven yer almaktadır. Arka cephesinde ana girişle aynı aksta ikinci bir giriş kapısı bulunmaktadır. Oda boyutları birbirine yakın olup, en geniş odalar köşelere yerleştirilmiştir. İkinci katta koridor, avlu boşluğunun etrafinı çevreleyecek şekilde yer almaktadır.

Giriş aksına göre simetrik bir cepheye sahip olan yapı, girişi öne çıkarılarak, saçak hizasında üçgen bir alınlıkla tamamlanmıştır. Geçmişte beş basamakla ulaşılan giriş mekânına günümüzde üç basamakla ulaşıımaktadır. Giriş kapısının tam üstünde dikdörtgen balkon çıkması yer almakta, bu çıkma dört ince sütun ile taşınmaktadır (Şekil 10). Sütunların araları düz atkı şeklinde kapatılmış olup, üzerine

\footnotetext{
${ }^{14}$ Tarih: 11/Ra /1309 (Hicrî) Dosya ${ }^{16}$ Develi, H, Ş, 2001, s. 70. No: 1878 Gömlek No: 94 Fon Kodu: ${ }^{17}$ Develi, H, Ş, 2007, s. 135. DH.MKT. $\quad{ }^{18}$ Tarih: 18/\$̧ /1323 (Hicrî) Dos${ }^{15}$ Tarih: 29/B /1319 (Hicrî) Dosya No: ya No: 1018 Gömlek No: 8 Fon 1389 Gömlek No: 39 Fon Kodu: I..DH.. Kodu: DH.MKT.
} 


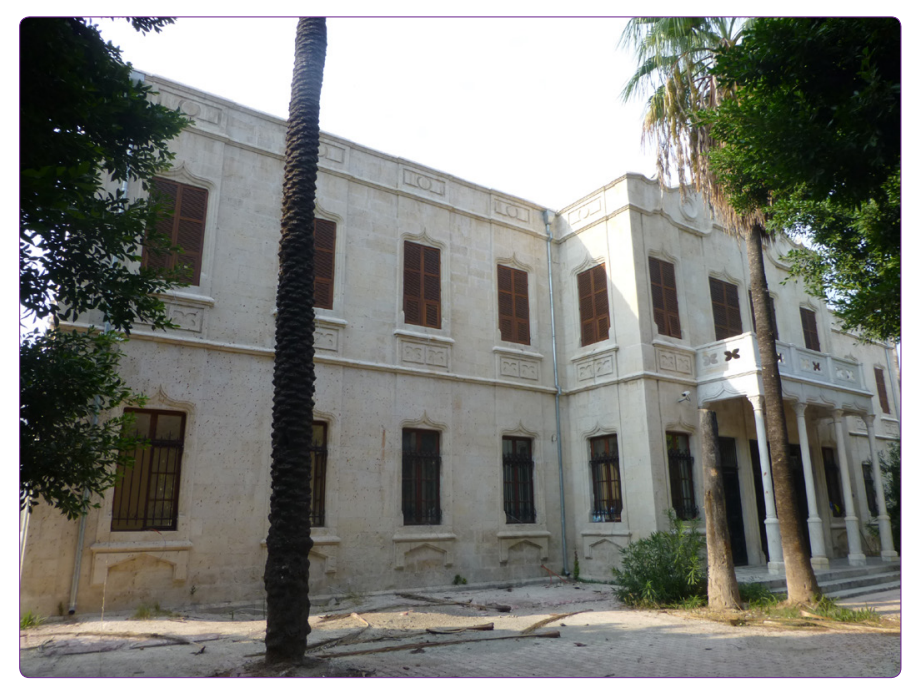

Şekil 10. Mersin Hükümet Konağı, 2014 (Kaynak: Nur Umar arşivi).

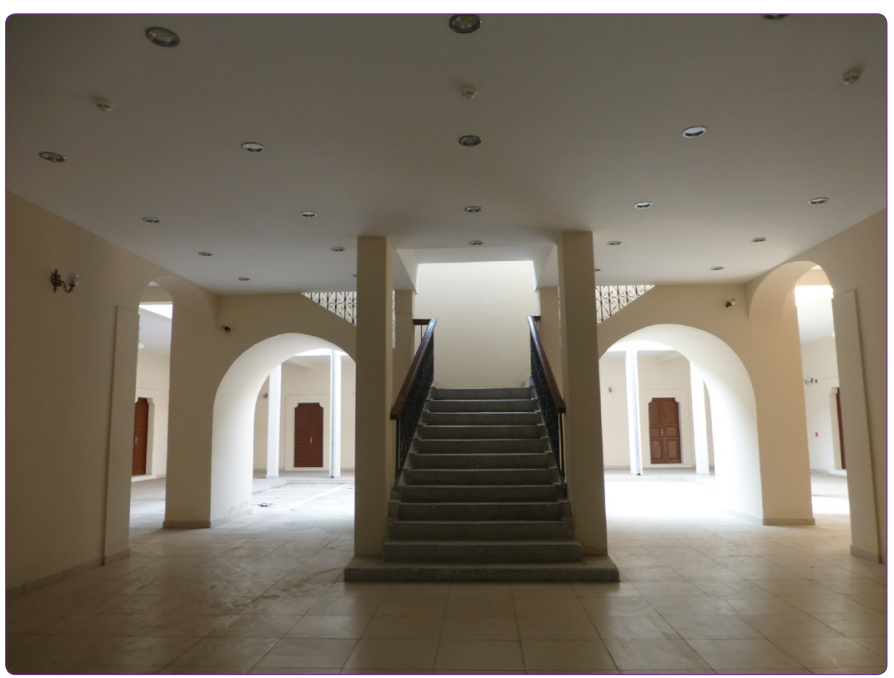

Şekil 11. Mersin Hükümet Konağı, İç Mekan, 2014 (Kaynak: Nur Umar arşivi).

kaş kemerler yapılmıştr. Pencereler ahşap panjurlu ve düz atkılı olup, çevreleri söve ile belirginleştirilmiştir. Üst sövelerin içinde kaş kemerler işlenmiştir. Pencere alt bölümleri birinci ve ikinci katlarda farklı bezemelerden oluşmuştur. Kat hizalarında ve çat birleşimlerinde silmeler yer almaktadır. Yapının diğer cepheleri, ön cepheye göre daha sade olmakla beraber, aynı pencere düzenini devam ettirmiştir. Günümüzde, kat döşemesi, iç mekânda yer alan kolonlar ve merdivenler betonarmeye çevrilmiştir (Şekil 11).

1925 yılında büyük bir yangın geçiren Hükümet Konağı'nın üst katında yer alan Nüfus, Tapu gibi daireler hasar görmüştür. ${ }^{19}$ Binanın tamiratı sırasında konağın ana cephesinde yer alan Osmanlı arması Atatürk rölyefi ile değiştirilmiştir. Özgün durumunda avlusunun ortasında bulunduğu bilinen büyük bir havuz, sonradan kaldırılmıştı. ${ }^{20}$

\footnotetext{
${ }^{19}$ Develi, H, Ş, 2007, s. 147.
}

Yapı, 2012 yılına kadar il Sağlık Müdürlüğü olarak kullanılmış olup, 2012-2014 yılları arasında restorasyon çalışması geçirmiştir. 2014 yılında restorasyon sonrası yapı yerinde incelenmiştir. Fotoğraflardan da anlaşıldığı üzere, Bu restorasyon çalışmasında, dış cephe büyük ölçüde korunmuş ve iç kısımların özgün mimarisinden farklı, betonarme olarak yeniden yapılmıştr. Pencere kapı doğramaları, korkuluklar, merdivenler, tavanlar ve yer döşemeleri yenilenmiştir.

\section{Silifke Hükümet Konağı}

Silifke Hükümet Konağı, Mersin ili, Silifke ilçesi, Saray Mahallesi, Cavit Erdem Caddesi üzerinde yer almaktadır. Osmanlı döneminde Silifke'ye ilk defa hükümet konağının inşası 12 Şubat 1883 tarihli belgede geçmektedir. ${ }^{21} \mathrm{Bu}$ belgede Silifke'nin sancak merkezi kabul edilerek hükümet konağı inşa edilmesinden söz edilmektedir.

Yapı, dikdörtgen planlı ve iki katlıdır. Her iki katta da plan, I şeklinde bir koridor ve çevresinde sıralanan odalardan oluşmaktadır. Girişin hemen yanında sonradan yapıldığı anlaşılan bir merdiven bulunmaktadır. Ön cephede yer alan ana giriş kapısı ile zemin kat koridoru arasında kot farkı olduğundan bir merdiven ile koridora ulaşılmaktadır.

Bina; prizmatik bir kütleye sahip, ince uzun bir yapıdır. Ana cephe giriş aksına göre simetrik özellikler göstermesine rağmen, giriş kapısının sağ tarafina eklenen kapı ile simetri bozulmuştur. Zemin kat pencereleri düz atkıIı olup, üstlerinde basık kemerler yer almaktadır; üst kat pencereleri dikdörtgen formda dairesel kemerlidir. Ana giriş kapısı merkezde yer almakta, üzerinde iki adet düz atkılı pencere bulunmaktadır. Arka cephesi, ön cephesi ile büyük oranda benzerlik göstermektedir. Sadece arka cephede ana giriş kapısının üzerinde dairesel kemerli büyük bir pencere yer almaktadır. Ön ve yan cepheleri kesme taş ile arka cephesi ise yüzeyi düzeltilmiş moloz taş ile yığma olarak inşa edilmiştir. Kat döşemesi sonradan betonarmeye çevrilen yapının pencere ve kapı doğramalarında ahşap kullanılmıştır.

23.06.2014 tarihli alan çalışmasındaki gözlemlere göre yapının yakın zamanda restorasyon geçirdiği anlaşılmaktadır. Pencere ve kapı doğramaları değiştirilmiş, iç mekânda yer döşemeleri ile tavan kaplamaları tamamen yenilenmiştir. Tavan; asma tavana dönüştürülmüştür. 1960 öncesini betimleyen tablolardan ve tarihi fotoğraflarından anlaşıldığı kadarıyla; kırma çatılı, giriş aksına göre simetrik bir cepheye sahip olan yapının giriş kapısının üzerinde iki taş sütunla taşınan kapalı bir çıkma ve ön cephede yer alan ikincil kapının yerinde pencere bulunmaktadır (Şekil 12). Günümüzde ise çıkma kaldırılmış olup, simetriyi bozan bu kapının sonradan açıldığı anlaşıımaktadır (Şekil 13).

${ }^{21}$ BOA, Tarih: 4/R /1300 (Hicrî) Dosya No: 2114 Gömlek No: 41 Fon Kodu: ŞD. 


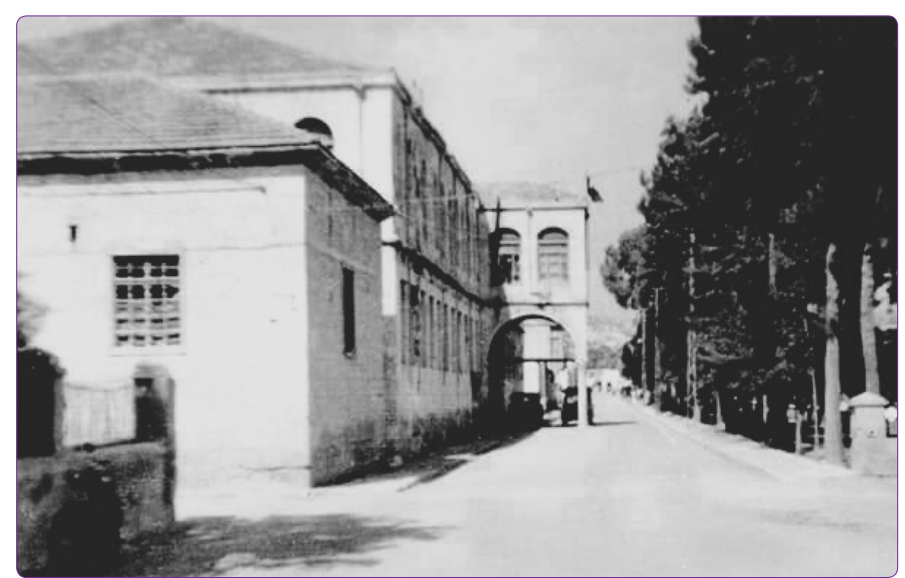

Şekil 12. Silifke Hükümet Konağı, 1925 (Kaynak: Abdul Kerim Parlatan Arşivi).

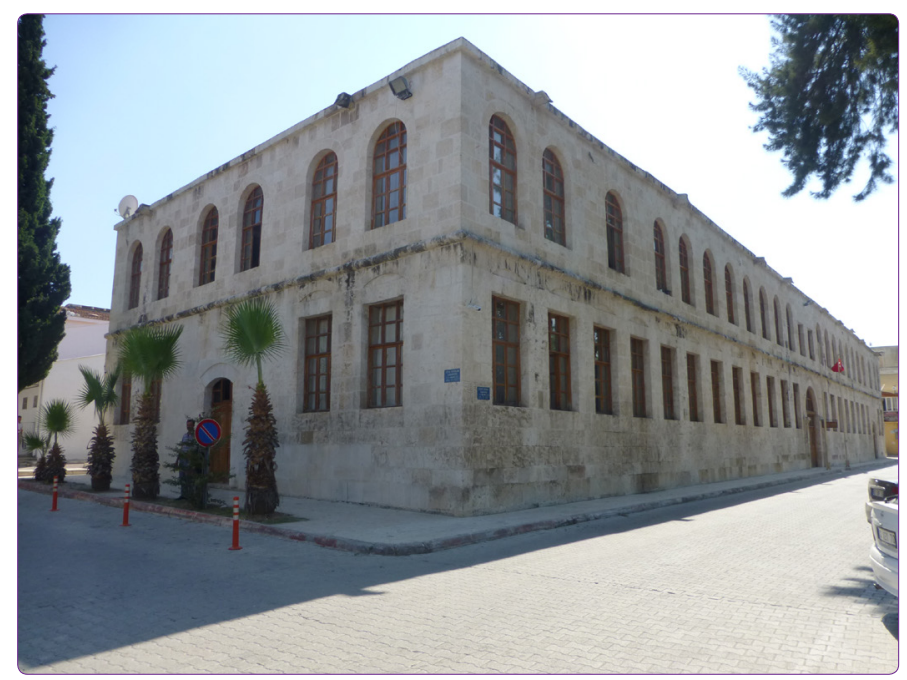

Şekil 13. Silifke Hükümet Konağı 2014 (Kaynak: Nur Umar arşivi).

\section{Anamur Hükümet Konağı}

Anamur Hükümet Konağı; Mersin ili, Anamur ilçesi, Yeşilyurt Mahallesi'nde yer almaktadır. Anamur'a yeni bir hükümet konağı yapılması ile ilgili ilk yazışmalar 1 Nisan 1907 tarihinde geçmektedir. ${ }^{22}$ Ancak, konağın yaptırıldığına dair kesin bir bilgi bulunmamaktadır. Günümüze ulaşmış olan Hükümet Konağı binası Cumhuriyet'in ilk yıllarında yaptrılmıştr. Cumhuriyet arşivi katalogları incelendiğinde 23 Ocak 1927 tarihinde inşaata başlanmış olduğu ve 1928 yılında da devam ettiği görülmektedir. ${ }^{23}$

Bina iki katlı ve dikdörtgen planlı olup, güneybat-kuzeydoğu doğrultusunda uzanmaktadır. Planda ana giriş aksı her iki doğrultuda ve ana giriş aksına simetri oluşturacak şekilde iki ayrı birim güneydoğu doğrultusunda dışarı çıkarılmıştır. Planda yapının yan cephelerinde girintiler oluşturulmuştur. Her iki katta da plan I şeklinde bir koridor ve bu

\footnotetext{
${ }^{22}$ BOA, Tarih: 17/S /1325 (Hicrî) Dos- ${ }^{23}$ BCA, Tarih: 23/1 /1927 (Miladi) Fon ya No: 1157 Gömlek No: 1 Fon Kodu: 30..18.1.1 Yer No: 22.85..15. Kodu: DH.MKT.
}

koridorun iki yanındaki odalardan oluşmaktadır. Giriş kapısının tam karşısında üst katla bağlantıyı sağlayan iki kollu bir merdiven yer almaktadır.

Giriş aksına göre simetrik cephe düzenine sahip olan yapının, ana girişi ile sağ ve sol yanında yer alan birimler dışa doğru çıkarılarak hareketlendirilmiştir. Bu çıkmaların köşeleri kesme taş görünümlü bezeme ile vurgulanmıştr. Buna ek olarak girişin hemen üstünde dört sütunla taşınan bir balkon çıkması yer almaktadır. Sütunlar birbirine sivri kemerlerle bağlanmıştır. Yapının birinci katında dikdörtgen formda basık kemerli, söveli ve kilit taşları belirginleştirilmiş pencereler, üst katta sivri kemerli söveli pencereler bulunmaktadır. Cephede tekli, ikili ve üçlü pencere düzeni oluşturulmuştur. Kesme taş malzemeden yığma olarak inşa edilmiştir. Kat döşemesi sonradan betonarmeye çevrilen yapının pencere doğramalarında ahşap, kapı doğramalarında metal kullanılmıştır (Şekil 14).

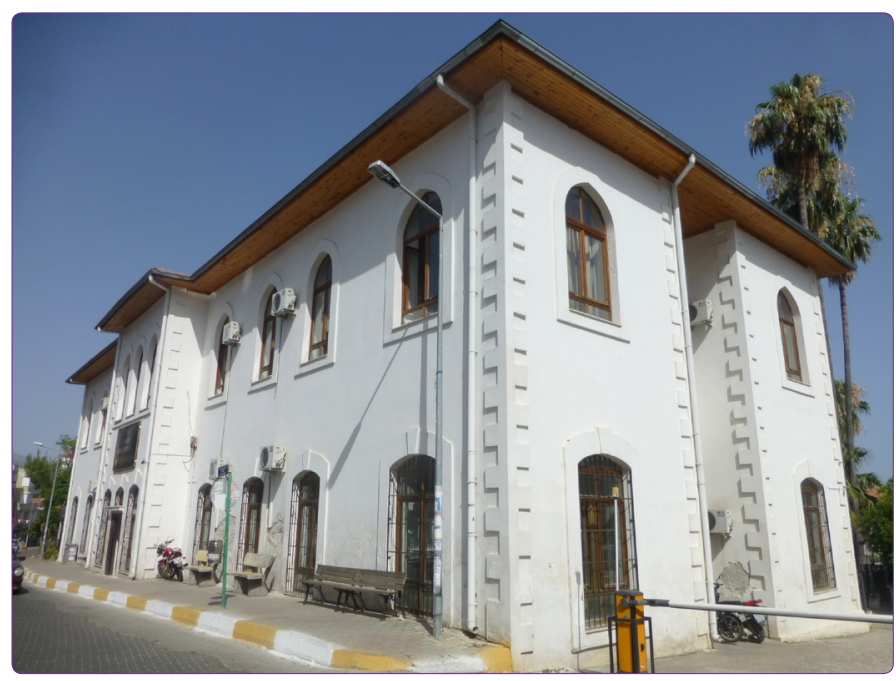

Şekil 14. Anamur Hükümet Konağı, 2014 (Kaynak: Nur Umar arşivi).

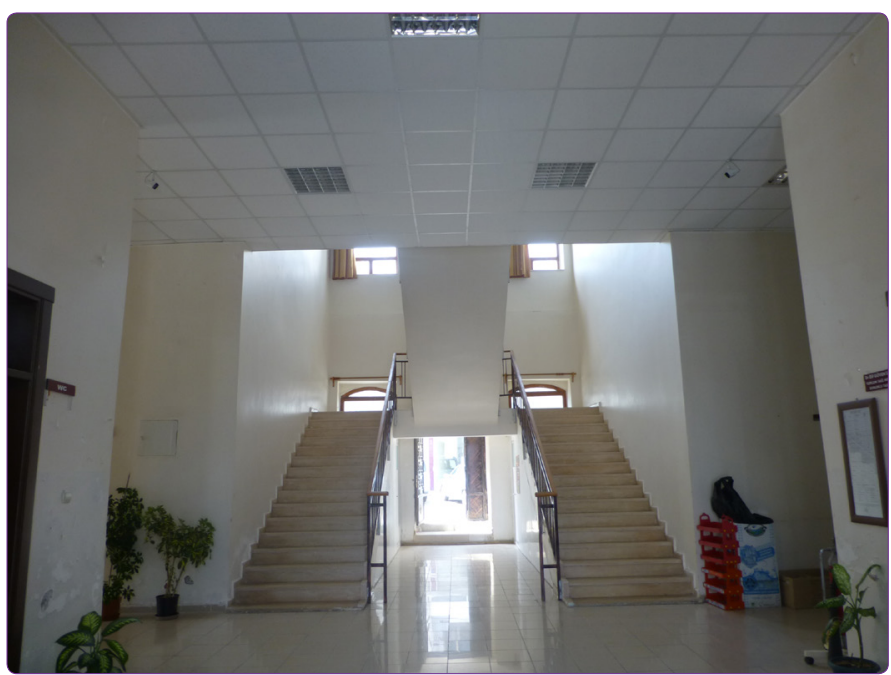

Şekil 15. Anamur Hükümet Konağı, İç Mekan, 2014 (Kaynak: Nur Umar arşivi). 
İnşa edildiği dönemden sonra uzun yıllar Hükümet Konağı binası olarak kullanılan yapı, 1995 yılında Mersin Üniversitesi Anamur Meslek Yüksekokulu'na tahsis edilmiştir. 2010 yılında restorasyon geçirmiş olup, günümüzde iliçe Sağlık Müdürlüğü olarak kullanılmaktadır. Restorasyon müdahalesi dâhilinde; cephesinin çimento esaslı malzeme ile sıvanarak boyanmış olduğu, pencere - kapı doğramaları ve zemin döşemelerinin değiştirilerek ve asma tavan ilave edildiği tespit edilmiştir. Biçimsel olarak özgünlüğünü koruyan yapının iç mekânından günümüze özgün bir eleman ulaşmamıştır (Şekil 15). 27.06.2014 tarihinde yerinde yapılan incelemelerde yapının taşıyıcılık durumunun iyi olduğu, sadece dış cephe sıvalarında kabarma ve dökülmeler olduğu gözlenmiştir.

\section{Hassa Hükümet Konağı}

Hassa Hükümet Konağı; Hatay ili, Hassa ilçesi, Dervişpaşa Mahallesi, Hürriyet Caddesi'nde yer almaktadır. Hükümet Konağı'nın tarihçesi, binanın giriş kapısı üzerinde yer alan kitabede detaylı olarak anlatılmaktadır. Bu Osmanlıca kitabeye göre; bina 1902 yılında, Sultan II. Abdülhamit'in tahta çıkışının 25. yıldönümü için inşa edilmiştir. Osmanlı Arşivi Hicri 12/Ş /1324 (1 Ekim 1906 M.) tarihli belgede ise Hassa kazası Hükümet Konağı ve bir çeşme inşaatının tamamlanarak açılışının yapıldığı bilgisi verilmektedir. ${ }^{24}$

Bina düz bir arazi üzerine kâgir/yığma sistemde bodrum + iki kat olarak inşa edilmiştir. Kareye yakın dikdörtgen bir plana sahiptir. Binanın ana cephesi ve giriş kapısı güneybatıda yer almaktadır. Binanın giriş katı planı ana bir hol ve iki yanında dizilen 4 odadan oluşmaktadır. Giriş kapısının tam karşısında merdiven yer almaktadır. Üst kat planı ise giriş kat ile benzerlik göstermekle birlikte oda sayısı bir tane fazladır. Bina içerisinde yeterince araştırma yapılamaması nedeniyle fazla olan odanın özgün olup olmadığına dair bilgi elde edilememiştir.

Binanın ana cephesi giriş aksına göre simetrik olup, girişi üçgen alınlıklı bir çıkmaya sahip, revaklı ve dairesel kemerlidir. Pencereleri dikdörtgen formda, basık kemerli olup, çevresi söve ve kilit taşı ile belirginleştirilmiştir. Beş basamaklı bir dış merdiven ile giriş kapısına ulaşımaktadır. Kemerli giriş kapısının üzerinde, binanın ilk yapıldığı tarihlerde eklenen kitabesi yer almaktadır. Üçgen alınlığın tam ortasında Osmanlı arması bulunmaktadır. Yan ve arka cepheler nispeten daha sade olup, yan cephede alt ve üstte olmak üzere 5'er pencere bulunmaktadır. Arka cephede üçlü-ikili-üçlü düzende 8 pencere, alt katta ise aynı hizalarda 6 pencere yer almaktadır. Ortadaki $2^{\prime} l i$ pencerelere denk gelen kısımda sonradan yapıldığı anlaşılan beş basamakla çıkılan bir kapı yerleştirilmiştir. En altta ise bodrum kata açılan havalandırma menfezleri görülmektedir. Günümüzde döşemeleri betonarme olup, yapıldığı dönemde özgün

\footnotetext{
${ }^{24}$ DH.MKT. Tarih: 12/\$̧ /1324 (Hicrî) Dosya No: 1121 Gömlek No: 88 Fon Kodu: DH.MKT.
}

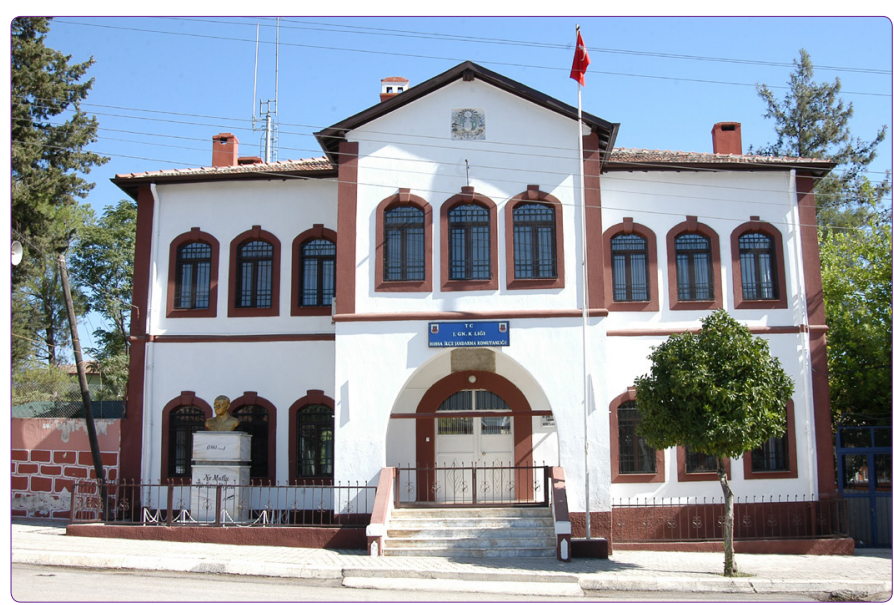

Şekil 16. Hassa Hükümet Konağı (Kaynak: Hassa Kaymakamlığı Arşivi).

döşemesinin ahşap olduğu düşünülmektedir. Yapının pencere doğramalarında ahşap, dış kapı doğramasında demir kullanılmıştır.

Bina Cumhuriyet sonrasında bir dönem kaymakamlık yapısı olarak kullanılmaya devam etmiştir. Ardından sırası ile Cezaevi, Öğrenci Yurdu, Milli Eğitim illçe Müdürlüğü binası, Halk Eğitim Merkezi ve II Özel İdare Binası olarak kullanılmıştır. ${ }^{25}$ Son zamanlarda ise Askerlik Şubesi olarak hizmet vermiş olup, Milli Savunma Bakanlığının 27 Mart 2012 tarihinde yeniden yapılanma kararı almasıyla $25 \mathrm{Ma}$ yıs 2012 tarihinde kapatılmıştr. Bir süre işlevsiz kalan bina, 14 Haziran 2013 yılında İlçe Jandarma Komutanlığı tarafindan restore edilerek yeniden hizmete açılmıştır (Şekil 16). Bu tarihten günümüze Jandarma Karargâh Binası olarak kullanılmaktadır. ${ }^{26}$

\section{Günümüzde Mevcut Olmayan Hükümet Konakları}

Bu bölümde, hükümet konağı olarak kullanılmak amacıyla 1869-1930 yılları arasında yaptrılan fakat yıkıldığı için günümüze ulaşamayan yapılar ile projesi hazırlandığı halde inşa ettirildiğine dair kesin bilgi bulunmayan yapılar ele alınmıştır.

\section{Haçin (Saimbeyli) Hükümet Konağı}

Osmanlı Arşivi incelendiğinde Kozan’a bağı Haçin kazasında var olan bir hükümet konağına ilişkin ilk bilgiye; "Haçin kazasında yapılması planlanan hükümet konağının inşası" olarak bahseden 4 Ağustos 1868 tarihli bir belgede rastlanmaktadır. ${ }^{27} 18$ Şubat 1872 tarihli belgede ise Kozan Sancağındaki Haçin kasabasında yapılan Hükümet Konağı'nın kat planlarını gösterdiği yazmaktadır. ${ }^{28} \mathrm{Bu}$ belgelere göre; Hükümet Konağı dikdörtgen planlı ve iki katlıdır (Şekil 17). Giriş katı geniş bir hol ve holün üç ya-

\footnotetext{
${ }^{25}$ Hassa Hükümet Konağı Dosyası, ${ }^{27}$ BOA, Tarih: 14/Ra/1285 (Hicrî) DosAdana Kültür Varlıklarını Koruma Ku- ya No: 6 Gömlek No: 322 Fon Kodu: rulu Arşivi, 10.06.2014 tarihli rapor. İ..ŞD.

${ }^{26}$ Hassa Hükümet Konağı Dosyası, ${ }^{28}$ BOA, Tarih: 06/Z /1288 (Hicrî) DosAdana Kültür Varlıklarını Koruma ya No: 646 Gömlek No: 44918 Fon Kurulu Arşivi. Kodu: I..DH.
} 


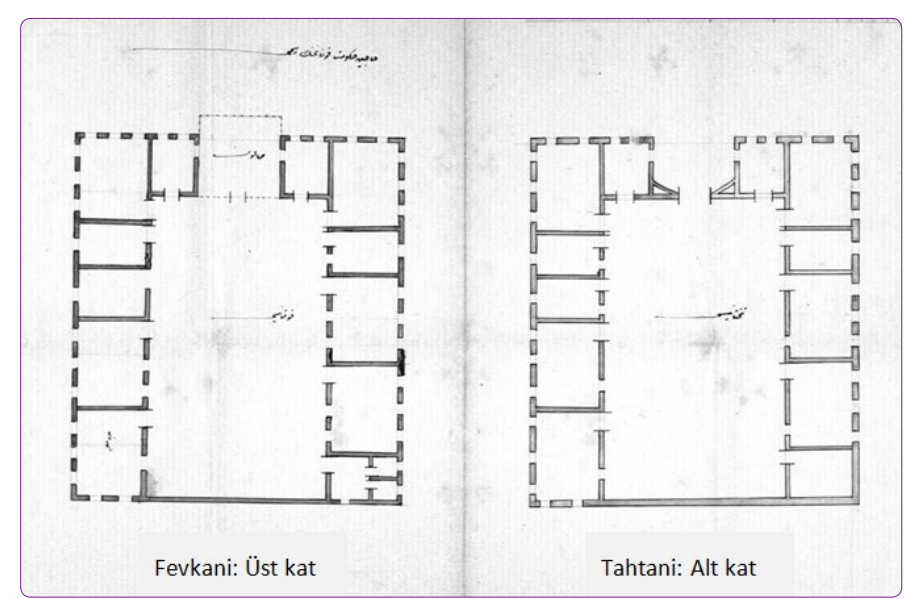

Şekil 17. Haçin Hükümet Konağı Planları (Kaynak: BOA, Tarih: 06/Z /1288 (Hicrî) Dosya No: 646 Gömlek No: 44918 Fon Kodu: i..DH..).

nına dizilmiş 12 adet farklı boyutlardaki odalardan oluşmaktadır. Bunlardan ikisi kareye yakın formda olup, girişin her iki yanında yer almaktadır. Diğer odalar hole karşıııklı olarak dizilmişlerdir. Üst ve alt kat planları birbirine benzer olup, sadece alt kattaki girişin bulunduğu kısım kapalı çıkma yapılarak salon olarak adlandırılmıştır. Koridorun en sonunda kalan bir odanın üzerine cami yazılmış, bu odanın karşısında yer alan bir mahal de plandan anlaşıldığı üzere hela olarak tasarlanmıştır. Bu planlarda dikkati çeken, iki kat bağlayan merdivenin yerinin gösterilmemiş olmasıdır. Arka cephede yer alan pencerelerin boyutlarına ve sayılarının azlığına bakarak daha sağır bir görünüm oluşturduğu söylenebilmektedir.

Günümüzde, 1872 yılında var olduğu söz edilen yapıya ait kat planları dışında başka bir belgeye ulaşılamamıştr. 1 Temmuz 1891 tarihli belgede ise Haçin Hükümet Konağı'nın harap olduğundan, tamiri ile ilgili belgenin resim ile birlikte gönderilerek mimariye uygun olup olmadığının Şehremanetine ${ }^{29}$ bildirilmesi gerektiğinden bahsedilmektedir. ${ }^{30} 13$ Temmuz 1892 tarihli belgede ise Haçin Hükümet Konağı'nın harap olmasından dolayı bir hanenin hükümet konağı olarak kiralandığı, kira bedeli ile ilgili gönderilen resmi yazıya uyulması gerektiği yazmaktadır. ${ }^{31} \mathrm{Bu}$ yazıdan anlaşıldığı üzere bu tarihlerde hükümet işlerini yürütmek için bölgedeki konutlar kiralanarak kullanılmaktadır. 30 Mayıs 1894 tarihli belgede ise Hükümet Konağı'nın yeniden yapıldığından masraflarla ilgili defterin gönderildiğinden bahsetmektedir. ${ }^{32}$ Günümüzde Saimbeyli ilçesinde yapılan incelemelerde konağa ulaşılamamıştır.

\section{Sis (Kozan) Hükümet Konağı}

Hükümet Konağı ilk 19 Temmuz 1866 tarihli belgede

\footnotetext{
${ }^{29}$ Bugünkü belediye teşkilâtının ${ }^{31}$ BOA, Tarih: 17/Z /1309 (Hicrî) Dosya Osmanlı Devleti'nde kurulan ilk No: 1970 Gömlek No: 74 Fon Kodu: şekli.

${ }^{30}$ BOA, Tarih: 24/Za/1308 (Hicrî) ${ }^{32}$ BOA, Tarih: 25/Za/1311 (Hicrî) DosDosya No: 1846 Gömlek No: 29 ya No: 165 Gömlek No: 7 Fon Kodu: Fon Kodu: DH.MKT.
}

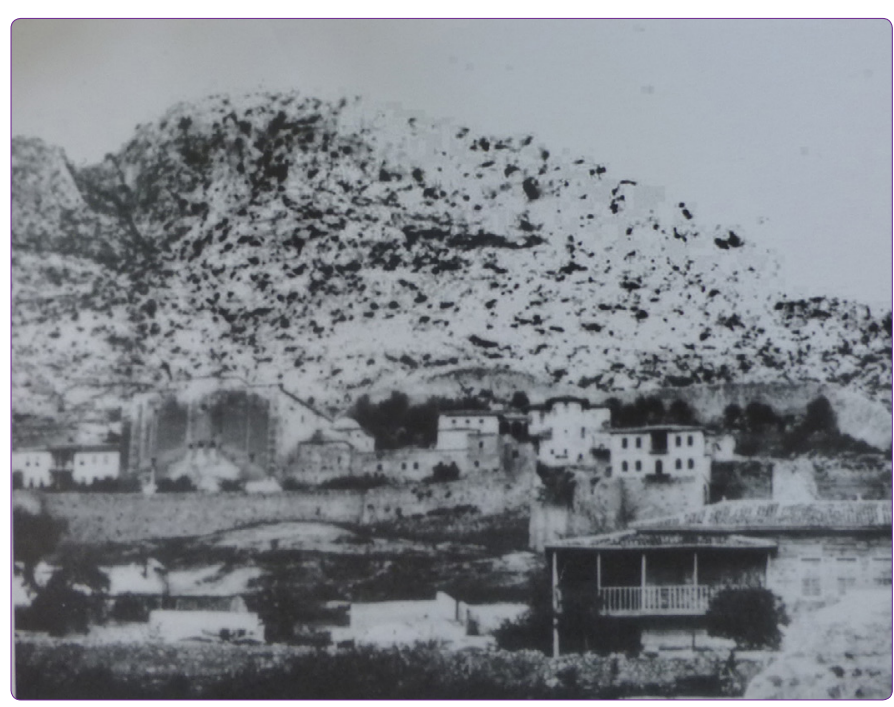

Şekil 18. Kozan Hükümet Konağı, 1920'ler (Kaynak: Kütük, A., (Tarih yok), Bir Zamanlar Kozan Ekrem Matbaası, Adana).

geçmekte olup, belgenin özetinde "Kozan kaymakamlığının merkezi olan Sis Kasabası'nda inşa edilen hükümet konağına dair" diye yazmaktadır. 21 Şubat 1905 yılına ait başka bir arşiv belgesinde ise Kozan Hükümet Dairesi'nin tamir masraflarının karşılanması gerektiği yazılıdır. ${ }^{33} \mathrm{Bu}$ belgeden, Kozan Sancağının merkezi olan Sis'te Hükümet Konağı'nın 1905 yılında da var olduğu çıkarımı yapılabilmektedir. 1920 tarihli Kozan haritasında da yapının yeri net bir şekilde görülmektedir. 1926 yılında ise yapının bilinmeyen bir nedenden ötürü yangın geçirdiği anlaşıımıştr. $^{34}$ Yangından sonraki durumu ile ilgili net bilgiler elde edilememiştir. Bazı kaynaklarda yapının yangından sonra belediye binası olarak kullanıldığı iddia edilmekle birlikte bunun doğruluğunu kanıtlayacak herhangi bir veriye ulaşılamamıştr. ${ }^{35} 1920$ 'li yıllara ait fotoğraflardan yapının kâgir malzeme ile yığma yapım sisteminde iki katlı ve kırma çatlı olarak inşa edildiği görülmektedir (Şekil 18). Sade bir üsluba sahip olan yapının önünde ahşap dikmelerle oluşturulmuş bir balkon çıkması yer almaktadır.

\section{Kadirli Hükümet Konağı}

Kadirli Hükümet Konağına ait ilk bilgiye; Başbakanlık Osmanlı Arşivi'nde, Kozan ve Kadirli'de hükümet konağı yaptrılmasına dair Halep Valisi'nin 13 Aralık 1866 tarihli cevap yazısında rastlanmaktadır. Araştırmalarda bu konakların inşa edilip edilmediğine dair bilgi edinilememiştir. $13 \mathrm{Ha}$ ziran 1867 tarihli belge Kadirli Hükümet Konağı'nın tamir masraflarının karşılanmasından söz ederken, 18 Ağustos 1899 tarihli belge de Kadirli'de hükümet konağı bulunmadığı için halktan toplanan paraların hükümet konağı inşaat için kullanılması istenmektedir. Bu bilgilere dayanarak,

\footnotetext{
${ }^{33}$ BOA, Tarih: 16/Z /1322 (Hicrî) Dos-

ya No: 933 Gömlek No: 24 Fon ${ }^{35}$ http://adanadantaraf.com/?/haKodu: DH.MKT.

${ }^{34}$ BCA, Tarih: 09/06/1926 (Miladi) Yer
} 
bu tarihler arasında mevcut Hükümet Konağı'nın yıkıldığı söylenebilmektedir. 1 Eylül 1900 tarihinde ise Hükümet Konağı'nın yeniden inşası için iki adet tapu gönderildiğinden söz edilmektedir. 15 Temmuz 2015 tarihinde yerinde yapılan incelemelerde hükümet konağının günümüze ulaşmadığı tespit edilmiştir. Bu yapıya dair detaylı bir bilgi, plan ve fotoğraflara ulaşılamamıştır.

\section{Payas Hükümet Konağı}

Payas Hükümet Konağı'nın inşası ile ilgili ilk bilgiye 21 Mayıs 1874 tarihli belgede rastlanmaktadır. ${ }^{36}$ Burada inşaat masrafları hakkında soruşturma yapılması gerektiği yazmakta olup, bu bilgiye dayanarak Payas Hükümet Konağı'nın inşa edildiği yargısına varılabilmektedir. Günümüzde yerinde yapılan incelemeler, belediye ve kaymakamlık gibi kurumlarla yapılan görüşmeler sonucunda yapının varlığı tespit edilememiş olup, mimarisi ile ilgili herhangi bir belgeye ulaşılamamıştır.

\section{Mut Hükümet Konağı}

1901-1902 Adana Salnamesinde, Mut Sancağında kalenin çarşıya bakan tarafinda burçlara bitişik şekilde büyük bir hükümet konağı yapılmış olduğu yazmaktadır. Yerinde yapılan incelemelerde bu yapıya rastlanmamış olup, ne zaman yıkıldığına dair bir bilgiye ulaşılamamıştır.

\subsection{Osmaniye Hükümet Konağı}

Osmaniye'ye hükümet konağı inşa edilmesi ile ilgili bilgilere 22 Mayıs 1908 tarihli bir “Hükümet Konağı'nın resmi, haritası ve keşfinin gönderildiği" yazan belgede rastlanmaktadır. ${ }^{37} 16$ Temmuz 1908 tarihli belgede Hükümet Konağı'nın yeniden ve yardımlarla inşa olunduğundan söz edilmektedir. ${ }^{38} 4$ Şubat 1914 'te ise Hükümet Konağı olarak kullanılan binanın kira ödemesinden bahsedilmektedir. ${ }^{39}$ Belgeden bu dönemde bir hanenin kiralanarak kullanıldığı anlaşılmaktadır. 2 Ağustos 1917 yılında Hükümet Konağı'nın halkın yardımlarıyla yeniden inşa edilmesi söz konusu olmuş, bu nedenle proje istenmiştir. ${ }^{40}$ A.K.V.K.K. arşivinde yapılan çalışmalarda 1920'li yıllarda Hükümet Konağı olarak kullanılan yapının fotoğraflarına ulaşılmıştır (Şekil 19, 20). Bu yapının BOA ${ }^{41}$ belgesinde söz edilerek projesi istenen yapı olma ihtimali vardır. Yapı, $80^{\prime}$ li yıllarda Trafik Tescil ve Denetleme Bürosu Amirliği olarak da kullanılmıştır. 1991 yılında özgünlüğünü kaybetmiş olduğu ve mimari açıdan niteliksiz olduğu öne sürülerek yıkılmıs ve yeri II Özel İdare Binası yapılmak üzere ihale edilmiştir. ${ }^{42}$

\footnotetext{
${ }^{36}$ BOA, Tarih: 04/R/1291 (Hicrî) Dosya No: 258 Gömlek No: 30 Fon Kodu: ŞD.

37 BOA, Tarih: 20/R /1326 (Hicrî) Dosya No: 3318 Gömlek No: 248783 Fon Kodu: BEO

${ }^{38}$ BOA, Tarih: 16/C /1326 (Hicrî) Dosya No: 3357 Gömlek No: 251722 Fon Kodu: BEO

${ }^{39}$ BOA, Tarih: 08/Ra/1332 (Hicrî) Dosya No: 28 Gömlek No: 37 Fon Kodu:

DH.MB..HPS.

${ }^{40}$ BOA, Tarih: 13/L /1335 (Hicrî) Dosya No: 24 Gömlek No: 27 Fon Kodu: DH.MB..HPS.

Başbakanlık Osmanlı Arşivi

${ }^{42}$ 02.12.1991 tarihli 720.01/32471453 sayılı Adana Valiliği II Kültür Müdürlüğünden Gönderilen Yazı, Osmaniye Hükümet Konağı DosyaSı, Adana Kültür Varlıklarını Koruma Kurulu Arşivi.
}

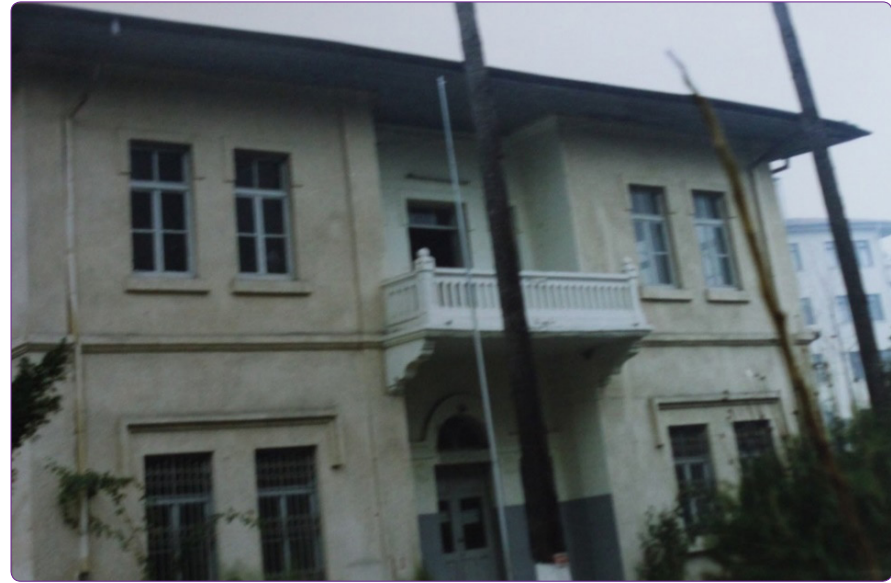

Şekil 19. Osmanliye Hükümet Konağı (Kaynak: Osmaniye Hükümet Konağı Dosyası, Adana Kültür Varlıklarını Koruma Kurulu Arşivi).

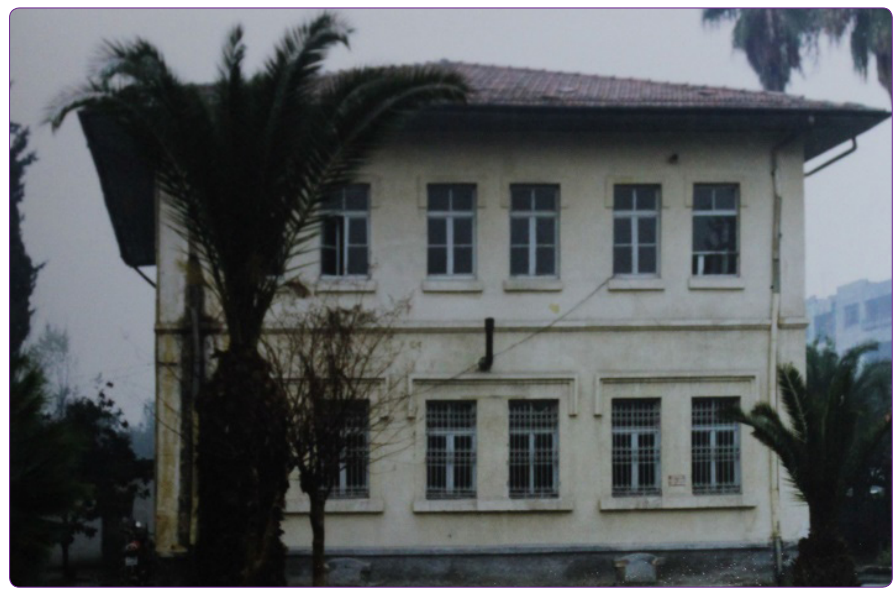

Şekil 20. Osmaniye Hükümet Konağı (Kaynak: Osmaniye Hükümet Konağı Dosyası, Adana Kültür Varlıklarını Koruma Kurulu Arşivi).

\section{Hamidiye (Ceyhan) Hükümet Konağı}

Hamidiye (Ceyhan) Hükümet Konağı ile ilgili ilk bilgiye 9 Kasım 1902 tarihli bir arşiv belgesinde rastlanmaktadır. Bu belgede Hamidiye kazası merkezinde bir hükümet konağı inşa edildiği ve resmî açılışının yapılarak padişaha dua edildiği bildirilmektedir. ${ }^{43} 29$ Mayıs 1319 (11 Haziran 1903) tarihli Servet-i Fünun dergisinde yapının fotoğrafi eklenerek yeni olarak inşa edilen Hamidiye Hükümet Konağı'nın açılış haberine yer verilmektedir. ${ }^{44}$ Bu fotoğrafa göre yapı tek katlı, simetrik cephelidir (Şekil 21). Giriş bölümü yükseltilerek öne çıkarılmıştır. Ana giriş kapısı dairesel kemerli olup, her iki yanında dairesel kemerli ince uzun birer pencere bulunmaktadır. Girişin üstü üçgen alınlıkla tamamlanmış olup, üçgen alınlığın ortasında Osmanlı arması yer almaktadır. Yapının ön cephesindeki pencereleri düz atkılı ve çevreleri ahşap pervazla çevrilidir. Günümüze ulaşamayan yapının yıkım tarihi ve nedeni bilinmemektedir.

\footnotetext{
${ }^{43}$ BOA, Tarih: 07/Ş/1320 (Hicrî) Dosya No: ${ }^{44}$ Servet-i Fünun Dergisi, 1903, 609 Gömlek No: 31 Fon Kodu: DH. MKT. $\quad$ sayı: 1894(633), s. 2.
} 


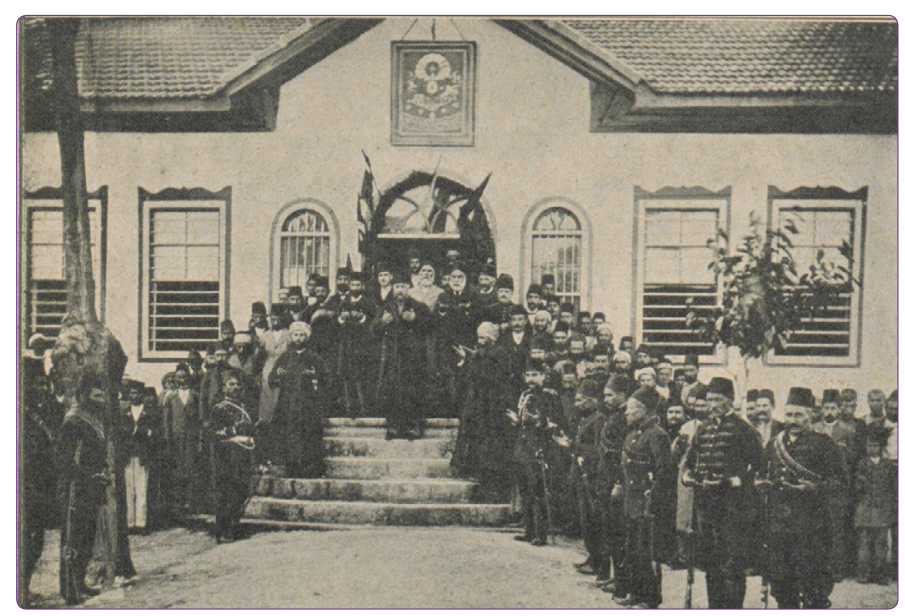

Şekil 21. Ceyhan Hükümet Konağı 1903 (Kaynak: Servet-i Fünun Dergisi, 1894(633): 2, 29 Mayıs 1319).

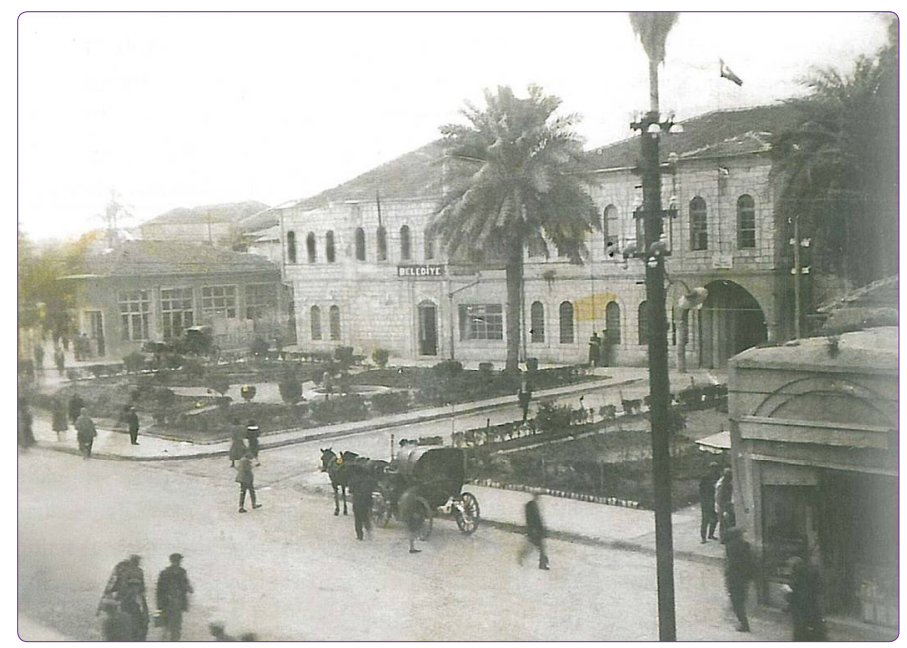

Şekil 22. Tarsus Hükümet Konağı (Kaynak: Öz, H., (2012). Yakın Tarihte Tarsus (1850-2000), Alev Dikici Basım, Adana).

\section{Tarsus Hükümet Konağı}

Tarsus'ta Hükümet Konağı'na ilişkin ilk bilgiye 6 Ocak 1867 tarihli, hükümet konağı olarak kullanılması için bir bina satın alınacağından bahseden bir belgede rastlanmaktadır. ${ }^{45} 3$ Ocak 1895 tarihli belgede ise ilk defa yeni yapılan Hükümet Konağı'ndan söz edilmekte; Tarsus'ta inşa edilmiş olan Hükümet Konağı'nın açılışının yapıldığı yazmaktadır. ${ }^{46} 5$ Ekim 1898 tarihli belgede ise Hükümet Konağı'nın tamir edilmesi planlanan bölümleri için gerekli paranın iletilmesini anlatmaktadır. 08.02.2014 tarihinde yerinde yapılan incelemelerde Tarsus Hükümet Konağı'nın günümüze ulaşmadığı tespit edilmiş olmakla beraber, ne zaman yıkılmış olduğu net olarak bilinmemektedir.

Yapının mimarisine dair bilgiler 20.yy ait bir fotoğraftan elde edilmektedir (Şekil 22). Bu fotoğrafa göre; yapı düz

\footnotetext{
${ }^{45}$ BOA, Tarih: 29/Ş /1283 (Hicrî) Dos- ${ }^{46}$ BOA, Tarih: 06/B /1312 (Hicrî) Dosya No :566 Gömlek No: 25427 Fon ya No: 31 Gömlek No: 26 Fon Kodu: Kodu: I...MVL.
}

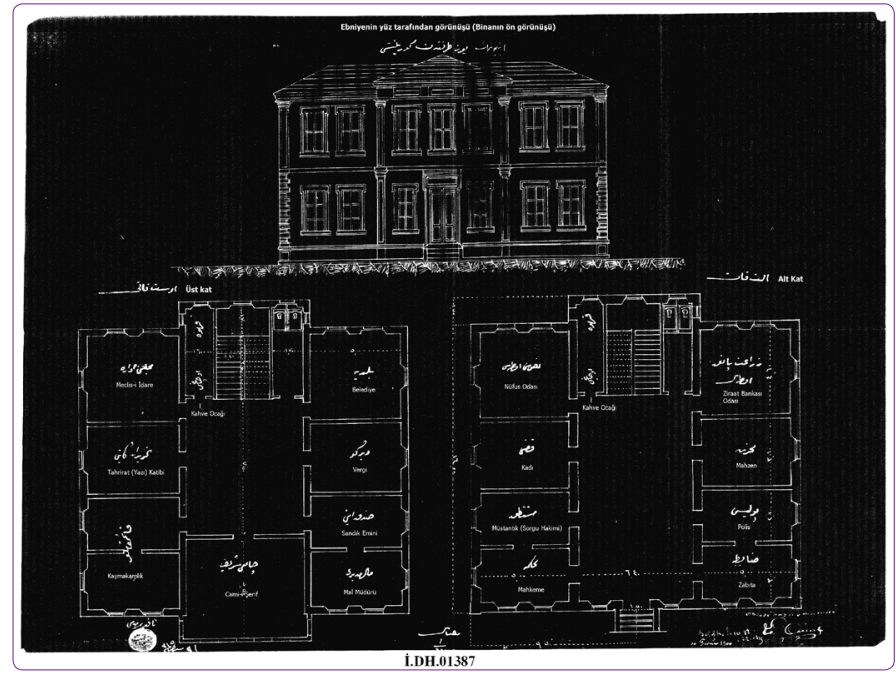

Şekil 23. Ermenek Hükümet Konağı Projesi, 1901 (Kaynak: BOA, Tarih: 02/C /1319 (Hicrî) Dosya No: 1387 Gömlek No: 39 Fon Kodu: I..DH..).

bir arazi üzerinde, Belediye Binası ile yan yana yerleşmiştir. Kesme taştan yığma yapım tekniği ile iki katlı ve kırma çatılı inşa edilmiştir. Sıvasız cephesinde, iki kat arasında yer alan kat silmesi dikkat çekmektedir. Binanın girişi çıkmalı olup, çıkmanın altında dairesel kemerli revak yer almaktadır. Dairesel kemerler iki adet sütuna oturmakta ve bu sütunların arasından geçilerek yapıya girilmektedir. Pencereler dikdörtgen formda dairesel kemerli olup, taş söveler ile belirginleştirilmiştir.

\section{Ermenek Hükümet Konağı}

İçel Sancağı merkezi olan Ermenek'te ilk defa hükümet konağı inşaatı 21 Haziran 1830 tarihli Osmanlı arşiv belgesinde geçmekte olup, ancak bu belgede yapıya dair detaylı bir bilgiye ulaşılamamaktadır. ${ }^{47} 24$ Eylül 1900 tarihli belgede halkın yardımlarıyla yeniden hükümet konağı yapılmasından bahsedilmektedir. ${ }^{48} 16$ Eylül 1901 tarihli belgede ise yapının inşaatına dair bilgiler verilmekte, yapının mimari çizimleri yer almaktadır ${ }^{49}$ (Şekil 23). 9 Ekim 1901 tarihinde yapının inşaatına izin çıktığı yazılmaktadır. ${ }^{50}$ Elde edilen mimari çizimlere göre; yapı $17.5 \times 19 \mathrm{~m}$ boyutlarında dikdörtgen planlı olup, iki kattan oluşmaktadır. Giriş katına 4 basamaklı bir merdivenle ulaşılmaktadır. Plan, dikdörtgen bir koridorun her iki yanına dizilmiş odalardan oluşmuştur. Girişin tam karşısında koridorun sonunda merdiven holü yer almaktadır. Merdivenlerin sağında helalar, solunda ise kahve ocağı bulunmaktadır. Giriş katta sol yandan başlayarak sırasıyla; mahkeme, müstantık, ${ }^{51}$ kadı ve nüfus odaları vardır. Sağ yanda ise odalar; zabıt, polis, mahzen ve ziraat bankası odası olarak sıralanmaktadır. Üst kat planı zemin

\footnotetext{
47 BOA, Tarih: 29/Z /1245 (Hicrî) Dosya No: $623{ }^{50}$ BOA, Tarih: 25/C /1319 Gömlek No: 30820 Fon Kodu: HAT. (Hicrî) Dosya No: 2542

${ }^{48}$ BOA, Tarih: 29/Ca/1318 (Hicrî) Dosya No: Gömlek No: 63 Fon Kodu: 2406 Gömlek No: 93 Fon Kodu: DH.MKT. DH.MKT.

${ }^{49}$ BOA, Tarih: 02/C /1319 (Hicrî) Dosya No: ${ }^{51}$ Sorgu hakimi. 1387 Gömlek No: 39 Fon Kodu: İ..DH..
} 


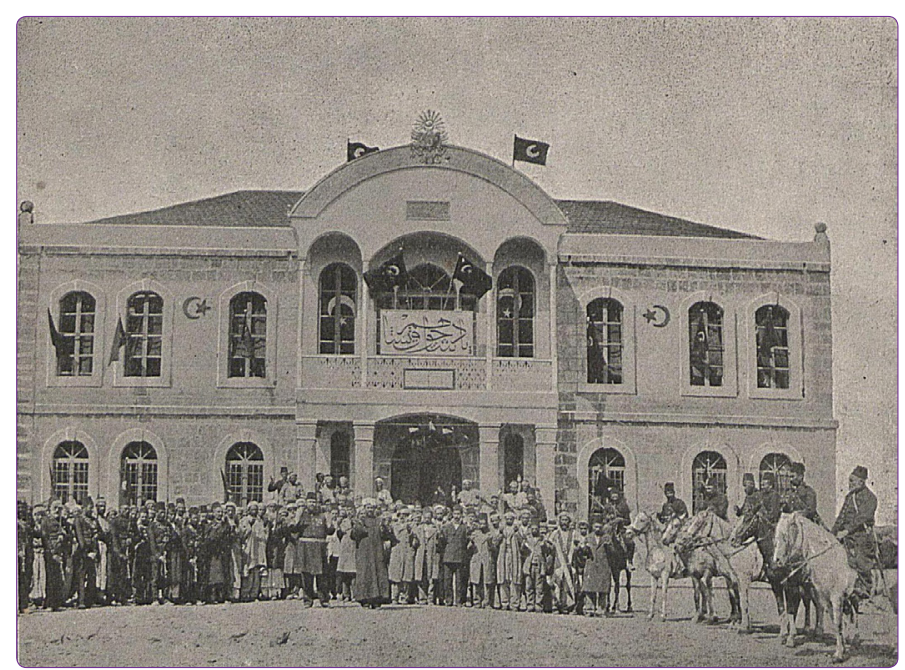

Şekil 24. İslahiye Hükümet Konağı, 1903 (Kaynak: Servet-i Fünun Dergisi, Sayı: 1894 (660): 1, 4 Kanunievvel 1319).

kat ile neredeyse aynı olmakla birlikte, koridorun biraz kısalarak giriş üstünün cami olarak tasarlanmış olması dikkat çekmektedir. Üst katta sol yanda kaymakamlık, tahrirat kâtibi, meclis-i idare; sağ yanda mal müdürü, sandık emini, vergi, belediye gibi birimler bulunmaktadır. Bu birimlerden anlaşıldığı kadarıyla hükümet konağı; polis, mahkeme, ziraat bankası ve belediye olarak da hizmet vermektedir.

25 Haziran 2014 yılında Ermenek merkezinde yapılan incelemeler ile fotoğraf arşivi taramalarında bu yapıya rastlanmamıştir.

\section{İslahiye Hükümet Konağı}

İslahiye Hükümet Konağı ile ilgili ilk bilgiye 17 Aralık 1903 tarihli Servet-i Fünun dergisinde rastlanmaktadır. ${ }^{52}$ Burada Hükümet Konağı'nın fotoğrafi yer almakta ve altında Padişah'ın tahta çıkışının yıldönümü olması nedeniyle resmi açılışı yapıldığı yazmaktadır. Bu fotoğrafa göre; iki katı ılan yapı kesme taş malzemeden yığma yapım tekniği ile inşa edilmiştir (Şekil 24). Binanın ana cephesi giriş aksına göre simetrik olup, girişte yarım daire şeklinde alınlığa sahip bir çıkma bulunmaktadır. Alınlığın en üstünde Osmanlı arması görülmektedir. Çıkma dört adet kolona oturmakta olup, üst kısımda bu kolonlarla aynı aksta balkon direklerinin devam ettiği görülmektedir. Ortada, sağda ve solda olmak üzere dairesel kemerli, çevresi taş söveler ile belirginleştirilmiş üçer pencere bulunmaktadır. Çatısı kırma çat olup, kiremit ile kaplıdır. 11.02.2015 tarihinde yerinde yapılan incelemelerde ise günümüze ulaşmadığı tespit edilmiştir.

\section{Değerlendirme ve Sonuç}

Adana Vilayeti hükümet konakları araştırması; literatür ve arşiv taraması, Osmanlıca belgelerin tercüme edilmesi, ardından arazi çalışması ile beraber yerinde tespit yapııma-

\footnotetext{
52 Servet-i Fünun Dergisi, 1903, sayı: 1894 (660), s. 1.
}

SI, koruma sorunlarının ve metotlarının araştırılmasından oluşmakta olup, 1867-1930 yılları arasında Adana Vilayetinin sınırlarında inşa edilmiş ya da projelendirilmiş tüm konakları kapsamaktadır. Çalışmanın kapsamı ve araştırma yöntemi doğrultusunda yerinde incelenen günümüze ulaşan yapılar ile tarihi fotoğraf, belge ve arşiv projelerine dayandırılarak değerlendirilen, günümüze ulaşmayan yapılar ele alınmaktadır. Bu verilerden yola çıkarak aşağıdaki değerlendirmeler yapılabilmektedir.

Adana Vilayetindeki hükümet konakları genellikle; şehir merkezlerinde konut yerleşimine yakın ancak bu yapılardan ayrıştırılmış olarak kamu yapılarının yoğunlaştığı bir bölgede inşa edilmişlerdir. Nehir kıyısı yerleşimi olan Adana kent merkezi ve Silifke'de genellikle nehrin bir yakasında manzaraya hâkim bir konumda yer almaktadırlar. Dönemin modernleşme hareketlerinden etkilenen şehircilik anlayışı doğrultusunda hükümet konağının önünün hükümet meydanı olarak düzenlenmesi, yalnızca Adana ve Tarsus'ta görülmektedir.

Yapım teknikleri çoğunlukla yığma/kâgir olan bu yapılar arasında Adana Hükümet Konağı, farklı olarak, taşıyıcı duvarları tuğla olarak inşa edilmiştir. Yapıların özgün biçimlenişinde; döşeme, merdiven ve çatida ahşap malzeme kullanılmıştır.

Osmanlı hükümet konağı binaları genel olarak dikdörtgen planlı, iki ya da üç katlı olarak inşa edilmiştir. Giriş cephesi daha süslü ve gösterişli tasarlanmış olup, giriş kapısı öne ya da geriye çekilerek vurgulanmıştır. Inşa edildikleri dönemin mimari eğilimini yansıtan bu yapıların, 20yy başlarından itibaren milli mimari üsluba göre şekillendikleri görülmektedir. ${ }^{53}$

Adana Vilayeti Hükümet konakları ise bu özellikler ile uyumlu, genelde dikdörtgen planlı ve iki katlıdır. Plan özelliklerini dört tipte ele almak mümkündür. Birinci tip; Adana, Anamur, Silifke hükümet konaklarında görülmektedir. Bu yapılar, uzunlamasına ince uzun bir koridor ve her iki yanında sıralanan odalardan oluşmaktadır. Giriş aksı, koridor aksını ortadan dik kesecek şekilde konumlanmıştır. Girişin tam karşısında iç merdiven bulunmaktadır.

İkinci tip; Hassa Hükümet Konağı ile Ermenek ve Saimbeyli (Haçin) Hükümet Konağı projelerinde görülen tiptir. Illk plana benzemekle birlikte bu yapılarda koridor, orta hol şeklini almıştır. Odalar, holün etrafinı çevrelemektedir ve girişin tam karşısında merdiven yer almaktadır.

Üçüncü tipe sadece Mersin Hükümet Konağı girmektedir. Dikdörtgen planlı olup, ortasında açık bir avlu yer almaktadır. Odalar, bu avlunun etrafinda sıralanmaktadır. ${ }^{54}$

\footnotetext{
53 Yazıcı, N, 2008.

${ }^{54}$ Bu plan tipi, çalışma alanı dışında kalması nedeniyle incelenmeyen fakat yakın çevrede yer alan, 1927-
}

28 yıllarında inşa edilen Hatay Hükümet Konağı'nın planı ile de benzerlik göstermektedir. 
Dördüncü tip ise ilk inşa edilen örneklerden biri olan Yarpuz Hükümet Konağında rastlanmaktadır. Bu plan tipi dikdörtgen şeklinde olup, kendi içinde bağımsız işleyen bölümlerden oluşmaktadır. Ortada yer alan yönetim kısmı iki katlıdır ve kendi içinde yer alan bir merdiven ile düşey olarak üst katlara ulaşım sağlanmaktadır.

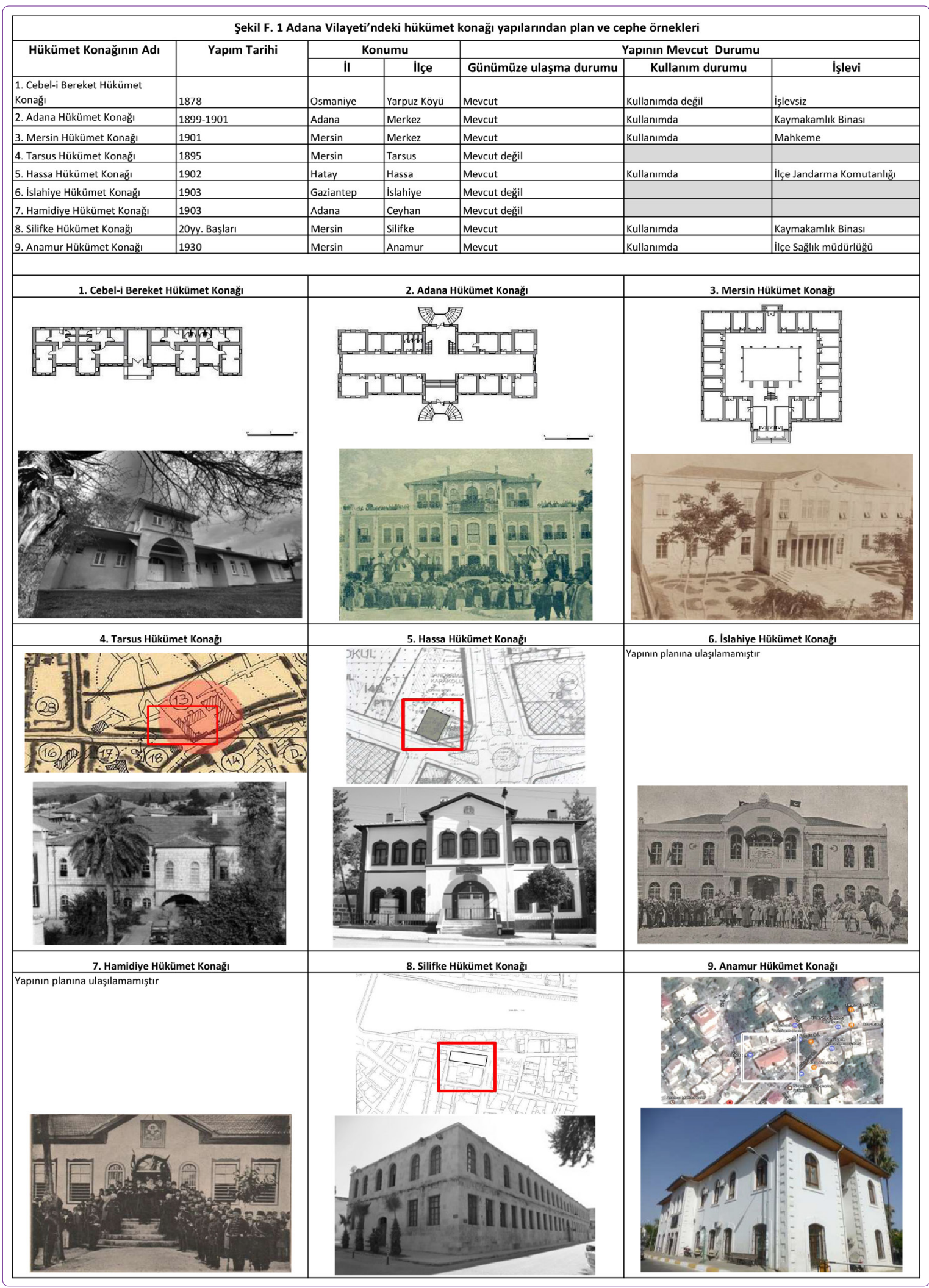

Şekil 25. Adana Vilayeti Hükümet Konaklarından Plan ve Cephe Örnekleri (Kaynak: Nur Umar arşivi). 
Hükümet konakları genellikle bodrum + zemin +1 katIı inşa edilmiş, giriş aksına göre simetrik bir cepheye sahiptirler. Kat yükseklikleri 4-5 metre arası değişmektedir. Ana giriş kapısı orta aksta yer almaktadır ve üst katlarda bir balkon ya da çıkma bulunmaktadır. Bodrum kat belirli bir oranda zemin kotundan yukarı çıkarılarak, bina girişi yükseltilmiş ve cephede vurgulanmıştır.

Adana Vilayetindeki hükümet konakları cephe özellikleri bakımından dört tipte incelenebilmektedir (Şekil 25). Illk ve en sık rastlanılan tip; İslahiye, Tarsus, Hassa hükümet konakları ile projesi incelenen Ermenek Hükümet Konağı'nda görülmektedir. Bu tipte yapı simetrik cepheli, bodrum + zemin + 1 katlı olup; girişin üzerinde çıkma yer almaktadır. Pencereler dikdörtgen formda dairesel kemerli ya da düz atkılıdır.

İkinci tip, Adana ve Mersin hükümet konaklarında görülmektedir. Genelde iki - üç katlı olan bu yapılarda giriş̧ bölümü tüm katlar boyunca öne çıkarılarak üst kata balkon eklenmiştir. ${ }^{55}$ Giriş bölümü dışında yan bölümlerinin de simetrik olarak öne çıktığı Anamur Hükümet Konağı da benzerlik göstermesi açısından bu gruba dâhil edilmiştir.

Üçüncü tip daha geç dönemde inşa edilen Osmaniye Hükümet Konağı'nda görülmektedir. Bu tipteki yapıda giriş bölümü geri çekilerek kapı üzerine balkon eklenmiştir.

Dördüncü tip olarak Silifke Hükümet Konağı'nın özgün cephe biçimlenişinden söz etmek mümkündür. Bu tip, sade ve asimetrik bir cepheden oluşmaktadır. Ana giriş kapısı orta aksta olup, üzerinde iki taş sütunla taşınan çıkma yer almaktadır.

Çalışma; 2013 yılında başlayıp 2017 yılında tamamlanmıştr. 20 yerleşim merkezinde yapılan incelemede, 18671930 yılları arasında 16 hükümet konağı yaptrııdığı anlaşılmıştır. Bunlardan 6'sının günümüze ulaşttğı, 10'unun günümüze ulaşamadığı tespit edilmiştir. Sözlü ve yazılı kaynaklar ile $\mathrm{AKVKK}^{56}$ arşivi incelemelerine dayanarak yapıların yok olma nedenlerini; yapıların tescillenmemiş olması, yıkılarak yerlerine betonarme bina yapılması, 1920'li yıllarda çıkan iç karışıklık ve savaş durumlarında yanması, doğal afetler ve bakımsızlık sonucu harap duruma düşmesi olarak sıralamak mümkündür.

Günümüze ulaşan hükümet konaklarının ise özgünlüklerini yeterince koruyamadıkları tespit edilmiştir. Cephe düzenlerini korumalarına rağmen iç mekânlarda bulunan özgün döşeme ve merdivenler betonarmeye çevrilmiştir. Döşeme ve tavan kaplamaları ile doğramaları değiştirilmiştir. Büyük kısmı halen kamu binası olarak kullanılmakta olup, restore edildikleri için taşıyıcı yapı olarak iyi durumdadırlar. Yarpuz Hükümet Konağı ise genellemeden farklı olarak özgün ahşap döşemesini muhafaza etmiş, işlevsiz ve taşıyıcı yapı olarak yakın dönemde herhangi bir güçlendirme çalışması yapılmamış olmasından dolayı orta durumdadır.

Günümüzde var olan hükümet konakları 19. yy 'da gerçekleşen Osmanlı Devleti'nin yönetimsel değişiminin Adana Vilayetindeki izleri olmaları ve 20. Yy 'daki kurumların temellerini oluşturmaları açısından önemlidir. Bunun yanı sıra 19. yy sonu 20. yy başına ait malzeme ve yapım tekniklerini barındırmaları; plan, cephe biçimlenişleri ve kütlesel boyutları ile özgün bir nitelik taşımaktadırlar. Varlıkları ile kent hafizasının canlı tutulmasına ve bulundukları yerleşimin özgünlüğünün ortaya çıkarılmasına katkı sağlamaktadırlar. Günümüze ulaşan 6 yapının geleceğe korunarak aktarılabilmesi için; afet risk yönetim planı hazırlanması, onarım ölçütleri belirlenmesi, işlevsiz olan yapılara uygun işlevler verilerek kullanımda sürekliliğin sağlanması, yapıların periyodik bakım ve kontrolünün yapılması, kullanıcılar ile ziyaretçilerin bilgilendirilmesi önerilmektedir.

\section{Kaynaklar}

Batur, A. (1985). "Batılılaşma Döneminde Osmanlı Mimarlığı", Tanzimat'tan Cumhuriyet'e Türkiye Ansiklopedisi, cilt: 4, s. 1038-1067.

Develi, H. Ş. (2007). Eski Mersinde Yaşam, Mersin, Kırkambar Kitabevi.

Develi, H. Ş. (2001). Dünden Bugüne Mersin (1836-1990), Mersin, Mersin Ticaret Odası Yayınları.

Ortaylı, i., vd. (1984). "Söyleşi: Osmanlı'dan Bugüne Hükümet Konakları", Yön: Güven Birkan, Mimarlık Dergisi, Sayı 84, S.315.

Topçubaşı, M. ve Eyüpgiller, K. (2010). "19. yüzyılda Kastamonu Eyaleti’nde Hükümet Daireleri “, iтÜ Dergisi Mimarlık Planlama Tasarım, Sayı 9, s. 108-120.

Toksöz, M. ve Yalçın, E., (1999). "Modern Adana'nın Doğuşu ve Günümüzdeki İzleri", Ed. Çiğdem Kafesçioğlu ve Lucienne Thys Şenocak, Abdullah Kuran için Yazılar, İstanbul, Yapı Kredi Yayınları, s. 436-452.

Ulaş, M. (2011). "Söyleşi: Osmanlı'dan Bugüne Hükümet Konakları", Yön: Güven Birkan, Mimarlık Dergisi, Sayı 84, S.54-56.

Yazıcı N. (2008). "Trabzon Örneğinde Tanzimat'tan Cumhuriyet'e Hükümet Konağı Binaları", Uluslararası Sosyal Araştırmalar Dergisi, Volume 1/5, s. 947-948.

\section{İnternet Kaynakları}

123 Yıllık Belediye Binası, http://adanadantaraf.com/?/haber/ oku/1601, [Erişim tarihi 30.01.2007].

\footnotetext{
${ }^{55}$ Hatay Hükümet Konağının cephesi öne çıkarılmamıştır.

de ikinci tip ile benzer biçimlenişte ${ }^{56}$ Adana Kültür Varlıkları Koruma Ku olup, farklılık olarak giriş bölümü rulu.
} 